Universidade de São Paulo

Instituto de Astronomia, Geofísica e Ciências Atmosféricas

Departamento de Geofísica

Caio Alencar de Matos

Modelagem e inversão de métodos potenciais do terreno granito-greenstone Rio das Velhas no Noroeste do Quadrilátero Ferrífero

São Paulo 



\section{Modelagem e inversão de métodos potenciais do terreno granito-greenstone Rio das Velhas no Noroeste do Quadrilátero Ferrífero}

Versão Corrigida. O original encontra-se disponível na Unidade.

Dissertação apresentada ao Departamento de Geofísica do Instituto de Astronomia, Geofísica

e Ciências Atmosféricas da Universidade de São Paulo como requisito parcial para a obtenção do título de Mestre em Geofísica.

Área de Concentração: Geofísica Orientador(a): Prof ${ }^{\mathrm{a}}$. Dr ${ }^{\mathrm{a}}$. Yara Regina Marangoni

São Paulo 



\section{Agradecimentos}

O presente trabalho foi realizado com apoio da Coordenação de Aperfeiçoamento de Pessoal de Nível Superior - Brasil (CAPES) - Código de Financiamento 001.

À Câmara Técnico-Científica da CPRM - Serviço Geológico do Brasil pela liberação para realizar este trabalho.

À todos que me ajudaram e, especialmente, à minha orientadora e aos geólogos Marcelo Marinho e Paulo Dias que muito me ajudaram neste trabalho.

Agradeço à minha mulher pelo apoio em todo o trabalho. 



\section{Resumo}

É comum o uso da modelagem gravimétrica de greenstone belts devido ao alto contraste de densidade entre as rochas que preenchem o greenstone (geralmente metamáficas

e metaultramáficas) e o seu embasamento (geralmente gnaisses e granitos). O presente trabalho faz uma estimativa da geometria do greenstone belt na região da cidade de Pitangui em Minas Gerais - Brasil. Para tal foram realizadas 5 sessões de modelos gravimétricos 2D usando como vínculos uma seção sísmica publicada, seções retiradas da inversão do vetor magnetização (MVI), que foi calculada sobre os dados magnetométricos e os limites geológicos mapeados. As modelagens apresentaram a estimativa da geometria do greenstone belt em profundidade, independente se ele aflora ou não. A profundidade máxima do greenstone belt variou de 1 a $5 \mathrm{~km}$, aproximadamente, sendo que a calha vai ficando mais rasa na porção Sul do greenstone belt. Os limites do corpo anômalo modelado mostraram um contato abrupto do greenstone belt com o embasamento. Os limites laterais (afloramentos ou não) foram estimados por meio do mapa gravimétrico de anomalia Bouguer. Um resultado importante da modelagem foi o prolongamento do greenstone belt à NW, sob o Grupo Bambuí.

Palavras-chave: modelagem gravimétrica; inversão do vetor magnetização; greenstone belt Pitangui. 



\section{Abstract}

It is common to use gravimetric modeling on greenstone belts due the high contrast density between the greenstone rocks (usually metamafic and metaultramafic) and its basement (usually gneisses and granites). The present work estimates the geometry of the greenstone belt near Pitangui city on the state of Minas Gerais - Brazil. To estimate the geometry five 2D gravimetric forward modeling sections are presented. The models were constrained by a published seismic section, sections obtained from the magnetization vector inversion (MVI), calculated from magnetometric data, and from geological contacts. The geometry of the greenstone belt is presented by the forward modeling, even in regions where the greenstone belt is not outcropping. The maximum depth of the greenstone belt ranged from approximately 1 to $5 \mathrm{~km}$; the models indicated that the maximum depth becomes shallower toward South. The anomalous modeled body edges present abrupt contacts between the greenstone belt and the basement. The lateral boundaries (outcrops or not) were estimated by Bouguer anomaly map. An important model result is an extension of the greenstone belt at NW under the Bambuí Group.

Keywords: gravimetric modeling; magnetization vector inversion; Pitangui greenstone belt. 



\section{Lista de Figuras}

2.1 Localização do greenstone belt região de Pitangui. . . . . . . . . . . . . . . . . 20

2.2 Mapa geológico da área de estudo com os perfis gravimétricos. . . . . . . . . . 21

2.3 Coluna litoestratigráfica. . . . . . . . . . . . . . . . . . . . . . . . . . . 22

2.4 Sísmica localizada a norte do greenstone belt. . . . . . . . . . . . . 24

2.5 Distribuição das estações gravimétricas na área de estudo. . . . . . . . . . . . . 26

3.1 Mapa da anomalia Bouguer em A. Mapa de anomalia Bouguer residual em B. 32

3.2 Mapa do campo magnético anômalo. . . . . . . . . . . . . . . . . . . . . . 34

3.3 (a) Mapa da primeira derivada vertical. (b) Mapa da amplitude do sinal analítico

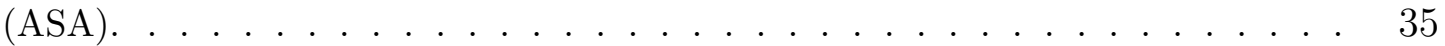

3.4 Bloco 3D de susceptibilidade magnética da área Campo Grande Pitangui resultante da MVI e a isosuperfície. . . . . . . . . . . . . 37

3.5 Bloco 3D de susceptibilidade magnética da área Serra Pequi-Jaguara resultante da MVI e a isosuperfície.. . . . . . . . . . . . . 38

3.6 Perfil Sísmica modelado. . . . . . . . . . . . . . . . 41

3.7 Perfil Conceição do Pará modelado. . . . . . . . . . . . . . . . . 43

3.8 Perfil Carioca Serra Grande modelado. . . . . . . . . . . . . . . . . . . . 44

3.9 Perfil Granito Jaguara modelado. . . . . . . . . . . . . . . . . . 46

3.10 Perfil Sul modelado. . . . . . . . . . . . . . . . . . . . . . 47

3.11 Mapa da anomalia Bouguer com curvas de isovalor. . . . . . . . . . . . . . 49

4.1 Perfil modelado Conceição do Pará sem a presença das rochas ultramáficas. 52

4.2 Perfil modelado Conceição do Pará sem a presença de um granito em sub-

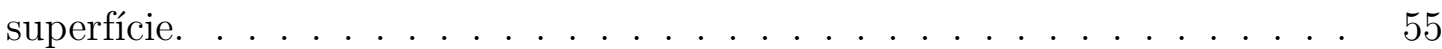


4.3 Seção MVI do perfil Carioca Serra Grande. . . . . . . . . . . . . . . . 56

4.4 Modelagens gravimétricas 2D colocadas sobre o mapa de anomalia Bouguer com a mesma escala lateral. . . . . . . . . . . . . . 59 59

4.5 Mapa de anomalia Bouguer com linhas de isovalor e interpretação do limites do GP. . . . . . . . . . . . . . . . . . . . . . . 61 
Lista de Tabelas

2.1 Tabela petrofísica. . . . . . . . . . . . . . . 23

3.1 Limites laterais do GP. . . . . . . . . . . . . . . . . 48 



\section{Sumário}

1. Introdução . . . . . . . . . . . . . . . . . . . . . . . . . . . . 15

1.1 Justificativa / Relevância . . . . . . . . . . . . . . . . . 18

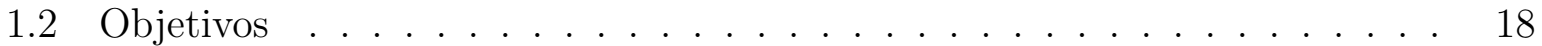

2. Materiais e Métodos . . . . . . . . . . . . . . . . . 19

2.1 Dados disponíveis . . . . . . . . . . . . . . . . . . . . . . . 19

2.1 .1 Geologia ....................... 19

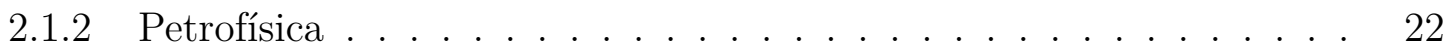

2.1 .3 Sísmica . . . . . . . . . . . . . . . . . . 23

2.1.4 Magnetometria ..................... 24

2.1.5 Gravimetria ..................... 25

2.2 Métodos . . . . . . . . . . . . . . . . . . 27

2.2.1 Inversão do vetor de magnetização (MVI) . . . . . . . . . . . . . 27]

2.2.2 Processamento dos dados GPS . . . . . . . . . . . . . . 27

2.2.3 Processamento dos dados gravimétricos . . . . . . . . . . . . 28

2.2.4 Modelagem gravimétrica direta 2D . . . . . . . . . . . . . 29

2.2.5 Limites laterais do greenstone belt . . . . . . . . . . . . . . . 30

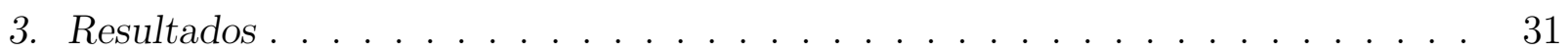

3.1 Mapas gravimétrico e magnetométrico . . . . . . . . . . . . . 31

3.2 Inversão do vetor magnetização $(\mathrm{MVI})$. . . . . . . . . . . . . . . . 36

3.3 Modelo direto gravimétrico $2 \mathrm{D} \ldots \ldots \ldots \ldots$

3.4 Limites laterais do Greenstone belt . . . . . . . . . . . . . . . . . . . . 48 
4. Discussão . . . . . . . . . . . . . . . . . . . . . . 51

4.1 Modelos 2D . . . . . . . . . . . . . . . . . . . . 51

4.2 Limites laterais . . . . . . . . . . . . . . . . . 60

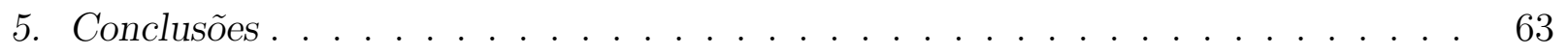

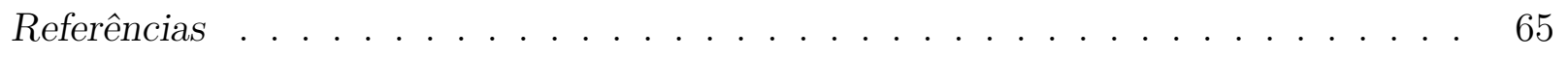


Capítulo 1

\section{Introdução}

O uso da modelagem gravimétrica é comum em greenstone belts e auxilia o entendimento de como estes corpos encontram-se alojados na crosta. Diversos trabalhos utilizam a gravimetria para estimar a profundidade e geometria dos greenstones belt:

Gupta et al. (1982) utilizaram a gravimetria para fazer uma modelagem direta 2D e estimar a profundidade do greenstone belt Birch-Uchi em Ontário, Canadá. Os autores indicaram uma profundidade máxima do greenstone belt de $5 \mathrm{~km}$ enquanto a estratigrafia da época estimava em $11 \mathrm{~km}$. A anomalia Bouguer do greenstone belt tem uma amplitude maior que +20 mGal.

De Beer (1982) usou gravimetria e sondagens elétricas verticais no greenstone belt Murchison localizado no cráton de Kaapval na África do Sul. As sondagens elétricas foram usadas para estimar a profundidade do greenstone belt em algumas localidades. As rochas do greenstone belt foram divididas em duas partes, uma rasa que sofreu intemperismo, mais condutiva, e o restante das rochas que preenchem o greenstone belt, mais resistivas. O embasamento formado por granitos/gnaisses apresentou uma menor resistividade que as rochas metavulcanossedimentares que formam a estratigrafia do greenstone belt. Os resultados das sondagens elétricas foram compatíveis com a modelagem gravimétrica a qual mostrou um greenstone belt com profundidade máxima de $7 \mathrm{~km}$, próximo aos $7,5 \mathrm{~km}$ da sondagem elétrica vertical.

Ranganai et al. (2008) fizeram o uso da gravimetria na porção centro-sul do cráton arqueano Zimbabwe. Nesse trabalho modelaram o greenstone belt Belingwe que, apesar dos mapeamentos geológicos, é pouco conhecido em subsuperfície. Foram modelados dois perfis. Os dados mostraram um contraste de anomalia Bouguer máximo de +40 mGal. A calha resultante teve profundidade máxima de $3,5 \mathrm{~km}$. 
Ranganai (2013) estudou o greenstone belt Fort Rixon-Shangani e o plúton Nalatale, Gwavava e Ranganai (2009) estudaram o greenstone belt Masvingo e seus plútons graníticos adjacentes, ambos os greenstone belts localizados no cráton do Zimbabwe. Ambos os estudos usaram mapas de magnetometria, gravimetria e realizaram modelagem direta gravimétrica para ajudar no entendimento geológico das áreas. Foram feitas correlações de anomalias com a geologia além das modelagens gravimétricas que estimaram a profundidade e geometria dos greenstones belt e plútons. O contraste da anomalia Bouguer na modelagem sobre o greenstone belt Fort Rixon-Shangani e sobre o greenstone belt Masvingo foi, aproximadamente, $+30 \mathrm{mGal}$, com profundidades máximas de $2 \mathrm{~km}$ e $5 \mathrm{~km}$, respectivamente.

Ramotoroko et al. (2016) no greenstone belt Madibe-Kraaipan no sudeste da Botswana contribuiu para o melhor entendimento geológico e estrutural a partir de mapas de magnetometria, gravimetria, derivada vertical (magnetometria), amplitude do sinal analítico (gravimetria e magnetometria), gravimetria residual, Euler 3D (magnetometria), espectro radial médio de potência (magnetometria) e modelagem direta gravimétrica. Nas modelagens gravimétricas o greenstone belt chegou a uma profundidade máxima de, aproximadamente, $5 \mathrm{~km}$. O contraste da anomalia Bouguer sobre o greenstone belt foi de, aproximadamente, $+30 \mathrm{mGal}$.

Le Pape et al. (2017) usou, principalmente, os métodos magnetotelúrico e gravimétrico nos greenstone belts Banfora e Houdé, dos crátons no Oeste Africano. A seção de condutividade invertida dos dados magnetotelúricos mostraram boa correlação com a modelagem gravimétrica do greenstone belt Houndé. Algumas anomalias gravimétricas foram coincidentes com porções condutoras. O greenstone belt Banfora não mostrou correlação com as porções condutoras. A anomalia Bouguer sobre os greenstone belts chegou a um contraste de, aproximadamente, $+20 \mathrm{mGal}$.

No Brasil, Souza et al. (1992) fizeram modelagens direta gravimétrica, com o auxílio da geologia de superfície, dos greenstone belts Serrinha e Identidade na região de Rio Maria, no Estado do Pará. Apesar do estudo ser preliminar ele trouxe informações de profundidade e mostrou que a faixa Serrinha é mais rasa que a faixa Identidade, com cerca de $4 \mathrm{~km}$ de diferença. O contraste da anomalia Bouguer sobre o greenstone belt Identidade chegou a valores de $+30 \mathrm{mGal}$.

Baltazar e Raposo 1993) fizeram a modelagem gravimétrica de um perfil com extensão 
de 190 km que vai da cidade de Cachoeira do Campo a Matipó, ambas no Estado de Minas Gerais. O objetivo principal do trabalho era uma modelagem regional, porém entre as feições do perfil está o greenstone belt Rio das Velhas, correspondente a um alto local da anomalia Bouguer com amplitude de $+25 \mathrm{mGal}$. O greenstone belt foi definido como duas camadas na porção superior de densidades 2900 e $2750 \mathrm{~kg} / \mathrm{m}^{3}$ e uma camada na porção inferior de densidade $2800 \mathrm{~kg} / \mathrm{m}^{3}$. A profundidade máxima é um pouco menor que $10 \mathrm{~km}$.

Blum et al. (2000) fizeram o uso da magnetometria e gravimetria para estudar três greenstone belts na região de Crixás, no Estado de Goiás: Crixás, Guarinos e Pilar de Goiás. Foi feita uma inversão gravimétrica 3D na área, que utilizou como vínculos medidas de furos de sondagem, geologia de superfície e medidas de laboratório de propriedades físicas. Foram retirados dois perfis de magnetometria e gravimetria onde foram realizadas inversões 2,5D e modelagem conjunta 2D. Sobre o greenstone belt Crixás o contraste de anomalia Bouguer foi de $+7 \mathrm{mGal}$ e a máxima profundidade de $0,7 \mathrm{~km}$. Já nos greenstone belts Guarinos e Pilar de Goiás o constraste da anomalia Bouguer chegou a valores de +25 mGal com profundidades da ordem de 1,5 km.

Em todos os estudos citados acima foi utilizada a gravimetria para estimar a geometria do greenstone belt e, na maioria dos casos, associada a algum outro método geofísica como magnetometria, magnetotelúrico, eletrorresistividade, etc. Apesar de não ser regra, as modelagens realizadas nos exemplos são caracterizadas por um alto gravimétrico sobre o greenstone belt. Esta característica ocorre devido aos greenstone belts serem preechidos, normalmente, por rochas máficas e ultramáficas que são mais densas que os gnaisses/granitos onde eles estão alojados. Essa propriedade faz com que a gravimetria seja uma técnica adequada para estimar a sua geometria. A profundidade máxima dos greenstone belts, nos estudos citados, mostra uma grande variação com valores menores que $2 \mathrm{~km}$ até cerca de $10 \mathrm{~km}$.

Os resultados da modelagem auxiliam o entendimento geológico e tectônico e permitem, em alguns casos, obter o comportamento das principais estruturas de primeira ordem em subsuperfície.

O presente trabalho faz o uso de dados gravimétricos para estimar a profundidade, geometria vertical e lateral da calha preenchida por sequências do tipo greenstone belt na porção noroeste do Quadrilátero Ferrífero, na região de Pitangui. Para facilitar iremos denominar essa sequência do tipo greenstone belt como Greenstone Belt Pitangui (GP). 


\subsection{Justificativa / Relevância}

O GP está situado ao sul do cráton São Francisco, e a noroeste do Quadrilátero Ferrífero. A área foi escolhida devido ao escasso número de estudos geológicos e geofísicos. Há poucos trabalhos sistemáticos de geologia, apesar de sua importância mineral e proximidade ao Quadrilátero Ferrífero. Na região já houve exploração de ouro por meio dos aluviões e minas. A mais importante exploração mineral da região ocorre sobre os agalmatolitos que contém materiais refratários de importância para a indústria de cerâmica (Romano e Soares, 2007).

A região já foi considerada uma prolongação da série Minas Guimarães e Barbosa, 1934), que é um supergrupo de grande importância na exploração de ferro no Quadrilátero Ferrífero. Costa e Romano (1976) consideraram as rochas metavulcânicas, metavulcanossedimentares e metassedimentares como pertencentes ao supergrupo Rio das Velhas do Quadrilátero Ferrífero. Frizzo et al. (1991) consideram estas rochas como pertencentes a um grupo a parte, o grupo Pitangui. Romano (1993) se opõe a esta separação e considera que estas rochas são iguais ao grupo Nova Lima, pertencentes ao supergrupo Rio das Velhas. Soares et al. (2017) acreditam que tanto o grupo Nova Lima quanto o grupo Pitangui podem ter originados de uma crosta Paleo-Meso Arqueana similar, porém não são grupos idênticos, desta maneira não é possível eliminar a discussão se o grupo Pitangui é distinto do grupo Nova Lima.

Se o GP pertence ao grupo Nova Lima ou é um grupo a parte ainda é uma discussão em andamento. Os resultados do presente trabalho podem auxiliar futuramente nessa discussão.

\subsection{Objetivos}

O presente trabalho faz o uso de dados gravimétricos terrestres para estimar a profundidade, geometria vertical e lateral das sequências do tipo greenstone belt do GP. As modelagens foram feitas sobre perfis gravimétricos com vínculos de dados de magnetometria, especificamente os resultados da inversão do vetor magnetização (MVI), e de uma linha sísmica, publicada, localizada na porção norte da área de estudo. A partir do mapa de anomalia Bouguer delimitou-se lateralmente o greenstone belt. 
Capítulo 2

\section{Materiais e Métodos}

\subsection{Dados disponíveis}

Para o presente trabalho foram utilizados dados de geologia, sísmica, gravimetria, magnetometria e petrofísica.

\subsubsection{Geologia}

O GP está localizado no estado de Minas Gerais, ao Sul do cráton São Francisco, onde o embasamento é aflorante, e à noroeste do Quadrilátero Ferrífero (Figura 2.1). Segundo Romano e Soares (2007) o GP foi depositado sobre uma bacia oceânica formada entre dois dois blocos de crosta continental, Belo Horizonte a NE e o Divinópolis a SW, que são essencialmente formados por gnaisses e migmatitos. Estes núcleos crustais são arqueanos e colidiram durante o mesoarqueano. O evento Transamazônico (2,26 Ga a 1,86 Ga) atuou sobre o GP imprimindo um caráter transcorrente transpressional na região.

O GP é composto por rochas similares as do Greenstone Belt Rio das Velhas: rochas metaígneas, metassedimentares e metavulcanossedimentares. Pelo mapa geológico da Figura 2.2, o greenstone belt é formado basicamente pelo grupo Nova Lima. No entorno do greenstone belt há a presença de granitos, granitoides e gnaisses. A norte do greenstone belt estão presentes coberturas sedimentares e rochas pertencentes ao grupo Bambuí. 


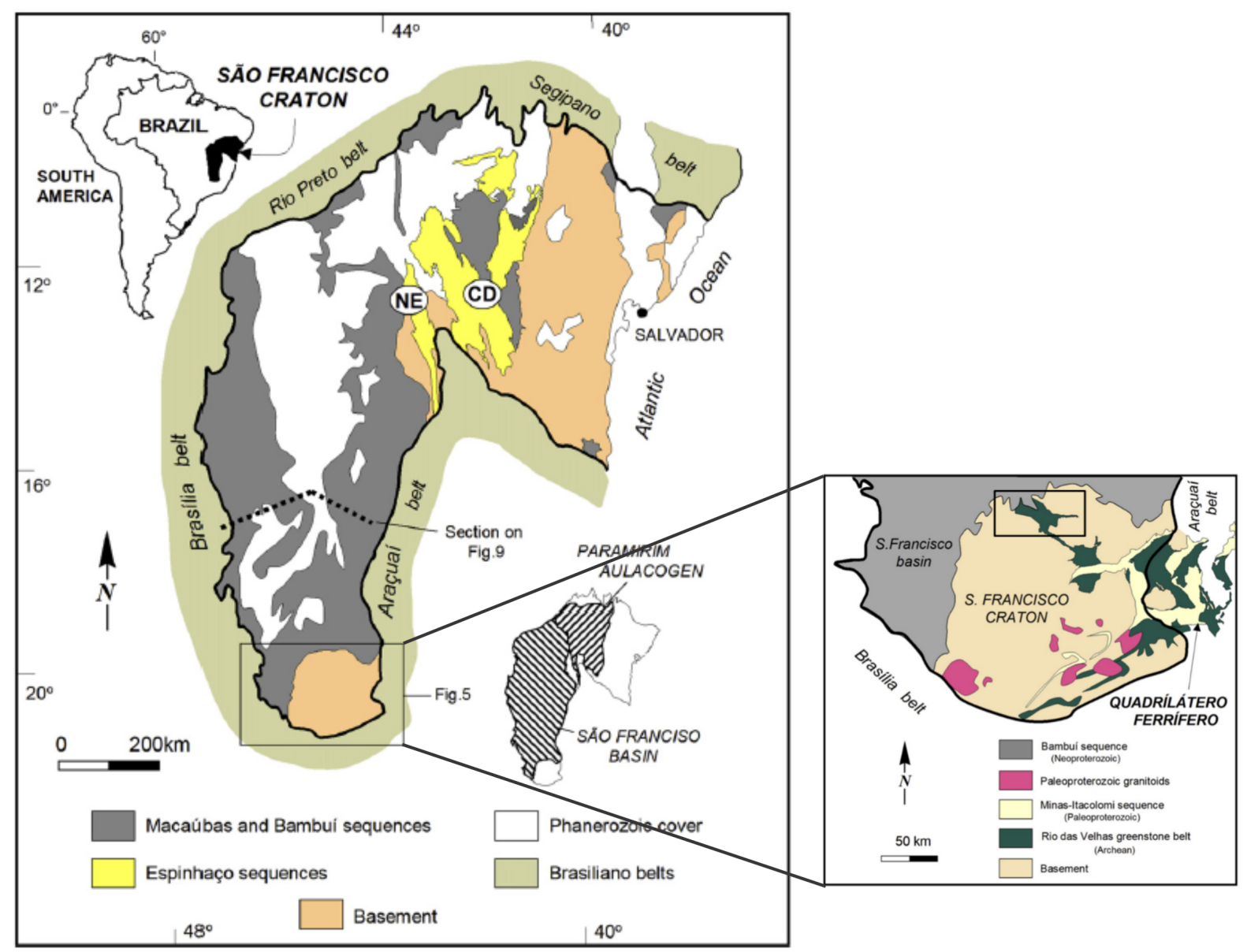

Figura 2.1: Esquema com a localização do greenstone belt da região de Pitangui. No esquema a direita ele está localizado na camada em verde demarcada pelo retângulo preto. Figura modificada de Alkmim e Martins-Neto (2012).

A litoestratigrafia, proposta por Marinho et al. (2018) e apresentada na Figura 2.3, foi utilizada como informação a priori na modelagem gravimétrica, uma vez que serve para estimar o intervalo de valores das propriedades físicas e definir a sequência das camadas com maior e menor densidade. 


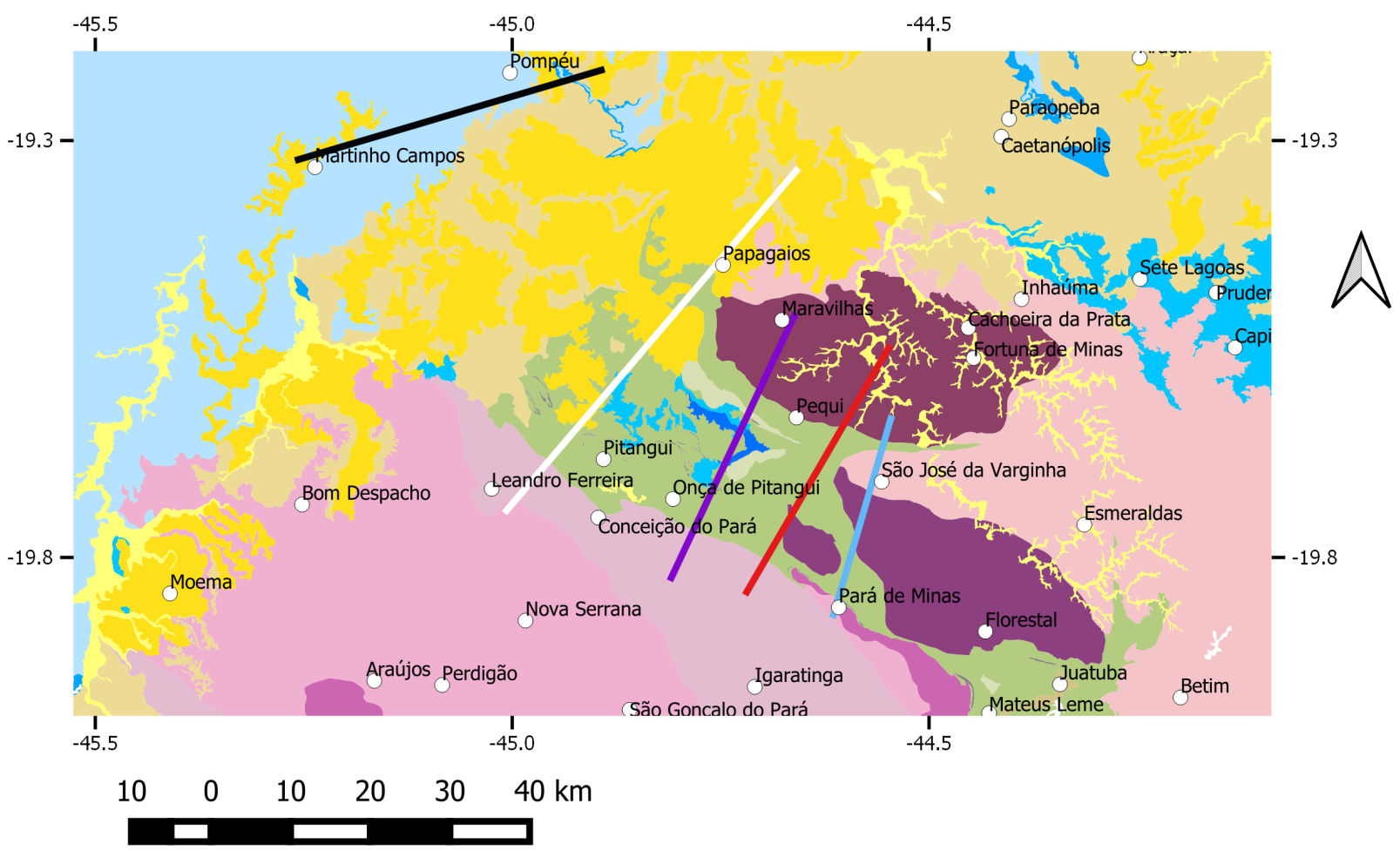

\section{Legenda}

Perfis gravimétricos

- Perfil Sísmica

Perfil Conceição do Pará

- Perfil Carioca Serra Grande

- Perfil Granito Jaguara

Perfil Sul

Geologia

Supergrupo Rio das Velhas - Grupo Nova Lima

Gnaisse BH

Gnaisse Cláudio

Gnaisse Itapecerica

Granitoide Florestal

Granitoide Maravilhas

Supergrupo Rio das Velhas - Grupo Maquiné Cobertura Superficial Indiferenciada

Grupo Bambuí - Fm. Juatuba

Grupo Bambuí - Fm. Carrancas

Grupo Bambuí - Fm. Sete Lagoas

Grupo Bambuí - Fm. Serra de Santa Helena

Grupo Bambuí - Fm. Lagoa do Jacaré

Grupo Bambuí - Fm. Serra da Saudade

Depósito Aluvial

Suíte Mato Dentro

Figura 2.2: Mapa geológico da área de estudo (Pinto et al. 2014). As linhas representam a localização dos perfis gravimétricos. 
RELAÇÕES TECTONO-ESTRATIGRÁFICAS

\begin{tabular}{|c|c|c|c|c|c|}
\hline ERA & PERIODO & EPOCA & $\begin{array}{c}\text { IDADE } \\
(\mathrm{Ma})\end{array}$ & & UNIDADES \\
\hline \multirow{5}{*}{$\begin{array}{l}O \\
\text { O } \\
N \\
O \\
己 \\
\text { DU }\end{array}$} & \multirow{5}{*}{ NEÓGENO } & HOLOCENO & & & \multirow{3}{*}{ Depósitos aluviais e de terraços } \\
\hline & & & 0,01 & \multirow[t]{2}{*}{ Q12a } & \\
\hline & & PLEISTOCENO & 2,58 & & \\
\hline & & PLIOCENO & 5,33 & \multirow{2}{*}{ Ndl } & \multirow{2}{*}{ Coberturas eluviais detrito-lateríticas } \\
\hline & & MIOCENO & 23.0 & & \\
\hline
\end{tabular}

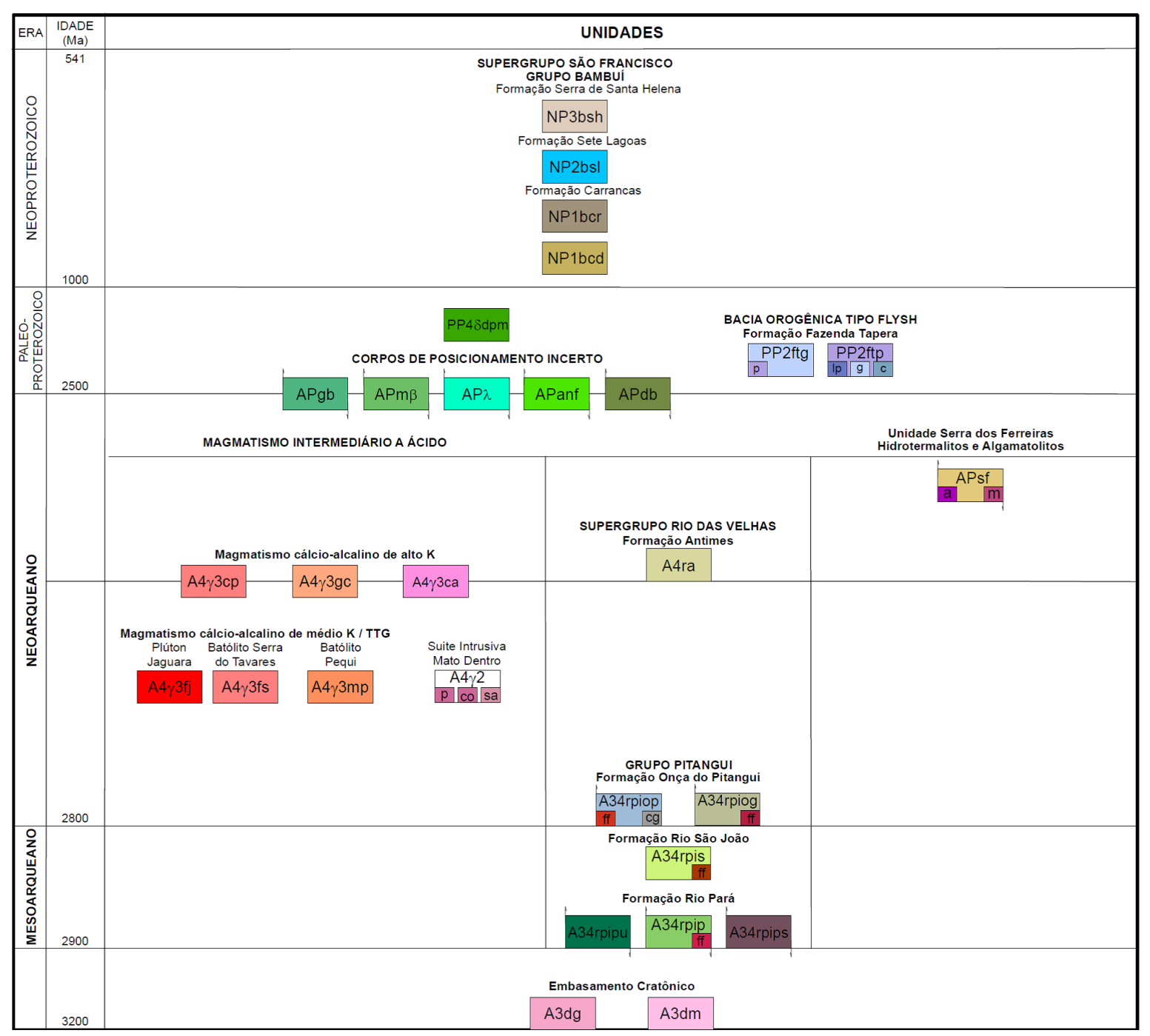

Figura 2.3: Coluna litoestratigráfica, (Marinho et al., 2018).

\subsubsection{Petrofísica}

A empresa Anglo Gold Ashanti disponibilizou (no ano de 2017) a tabela 2.1 com propriedades físicas médias de algumas sondagens. Estas sondagens estão localizadas no Quadrilátero Ferrífero, local que contém rochas similares as rochas do GP. Os dados desta tabela foram utilizados para estimar a velocidade das ondas $\mathrm{P}$ e o contraste de densidade 
entre as litologias.

Tabela 2.1 - Dados petrogeofísicos disponibilizados pela Anglo Gold Ashanti (2017).

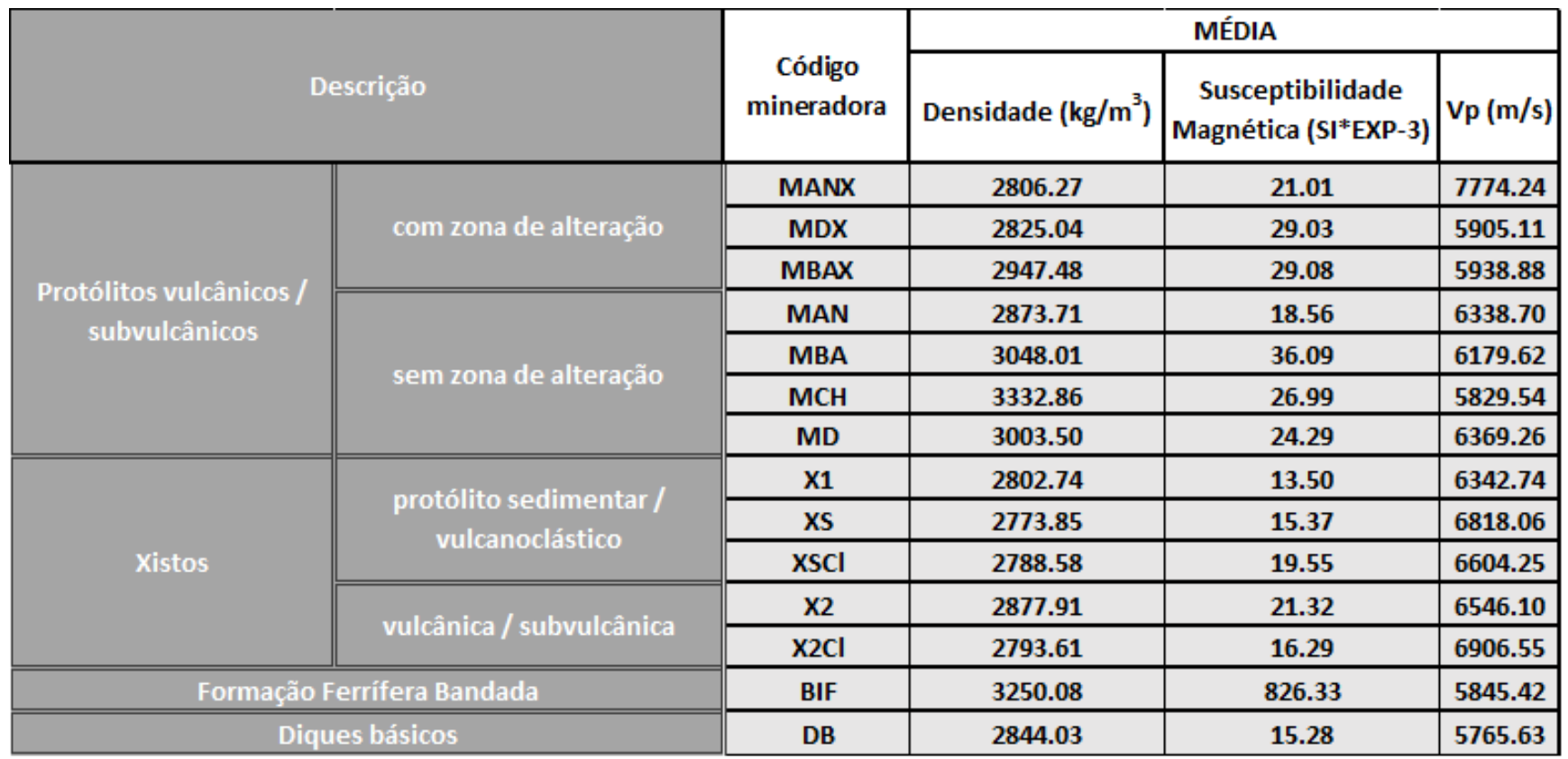

\subsubsection{Sísmica}

Reis et al. (2017) publicaram seções de sísmica de reflexão próximas à área de estudo. A sísmica utilizada nesse trabalho (Figura 2.4 começa próximo a cidade Martinho Campos e vai até depois da cidade Pompéu. Não tivemos acesso aos dados da sísmica, portanto, não foi possível processar de maneira a obter um modelo de velocidade adequado. Por esta razão, a sísmica foi tratada para estimar a profundidade dos refletores usando dados de velocidade das ondas $\mathrm{P}$ da Tabela 2.1 e estimativas da velocidade das ondas $\mathrm{P}$ no grupo Bambuí a partir dos dados de poço publicados no mesmo artigo. As coordenadas de início e fim da linha sísmica foram obtidas através do mapa publicado. A sísmica foi georreferenciada no software Oasis Montaj, no módulo GMSYS, e colocada como imagem de fundo, para modelagem neste mesmo módulo. Na modelagem tentou-se ao máximo incluir como vínculo as interfaces inferidas nas seções de sísmica de reflexão. 
(A)

(B)

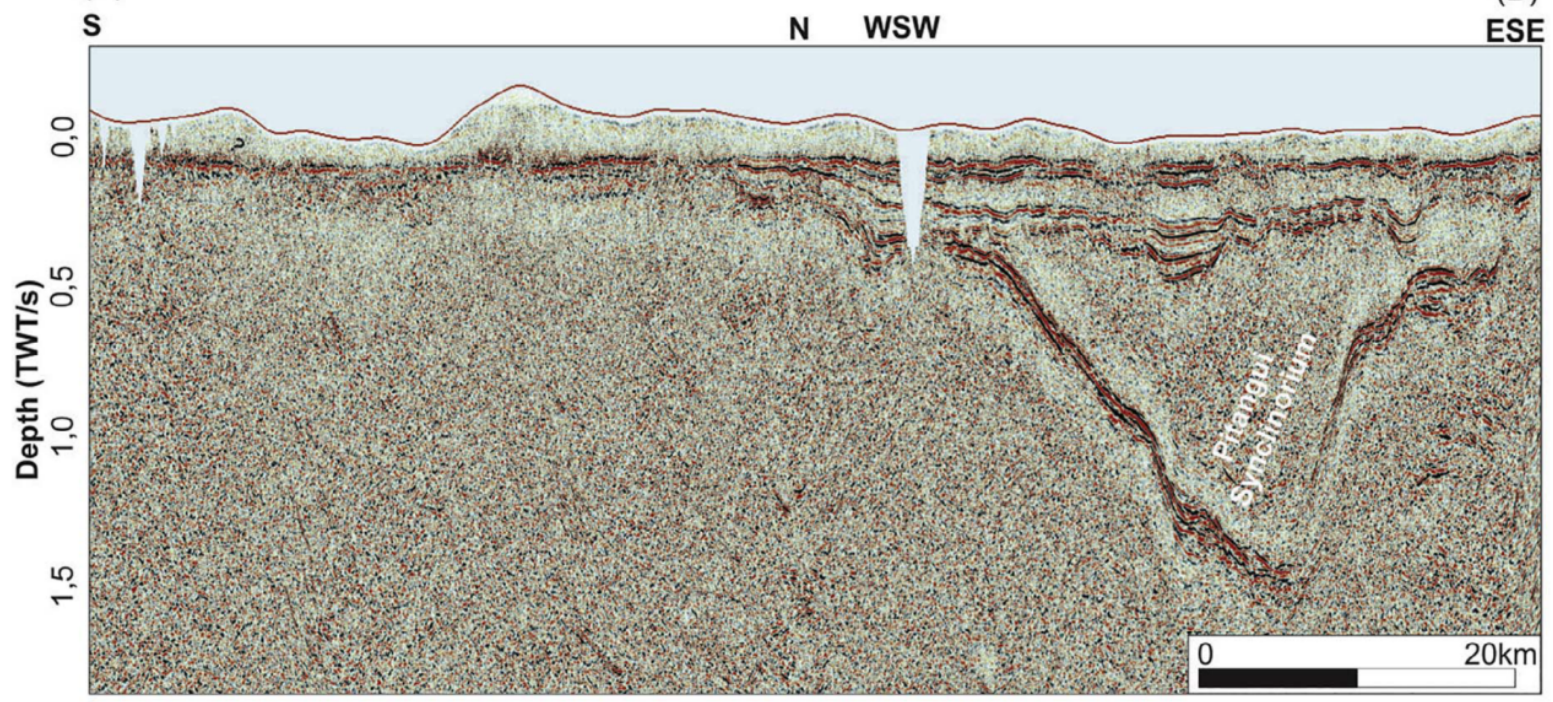

Figura 2.4: Sísmica utilizada na modelagem. Imagem retirada de Reis et al. (2017).

\subsubsection{Magnetometria}

Para a magnetometria foram utilizados os levantamentos geofísicos aéreos da CODEMIG/CPRM:

- MINAS GERAIS AREA 02 - PITANGUI-SÃO JOÃO DEL REI - IPATINGA:

- Ano de execução: 2001;

- Altura de voo: 100 m;

- Espaçamento entre as linhas: 250 m;

- Executora: FUGRO.

- MINAS GERAIS AREA 07 - ARAXÁ-PATOS DE MINAS-DIVINÓPOLIS:

- Ano de execução: 2006;

- Altura de voo: 100 m;

- Espaçamento entre as linhas: $400 \mathrm{~m}$;

- Executora: LASA.

- MINAS GERAIS AREA 10 - BELO HORIZONTE - CURVELO - TRÊS MARIAS: 
- Ano de execução: 2006;

- Altura de voo: 100 m;

- Espaçamento entre as linhas: 400 m;

- Executora: LASA.

Dentro do banco de dados de cada levantamento há uma coluna do campo magnético anômalo a qual se refere ao levantamento corrigido e subtraído do campo magnético internacional de referência (IGRF). A partir destes dados foi realizado o grid de cada levantamento. Os aerolevantamentos foram unidos utilizando a função Grid knit do Geosoft, foi gerado um mapa do campo magnético anômalo que cobre toda a área de estudo.

Após confeccionar o mapa foi realizada, sobre algumas anomalias, a inversão do vetor magnetização (MVI), elaborada por Ellis et al. (2012). Foram escolhidas duas áreas para o cálculo da MVI. As áreas escolhidas apresentam anomalias magnéticas localizadas em regiões por onde passam os perfis gravimétricos.

\subsubsection{Gravimetria}

Durante o ano de 2017, a CPRM adquiriu cerca de 280 novas estações gravimétricas complementando um levantamento inicial de 2015. Estes perfis foram adquiridos para o presente trabalho. A este conjunto de dados, adicionamos aqueles cedidos pelo Banco Nacional de Dados Gravimétricos (BNDG-ANP) que incluem aquisições de diversas instituições. A distribuição das estações gravimétricas disponíveis para este estudo está na Figura 2.5. 


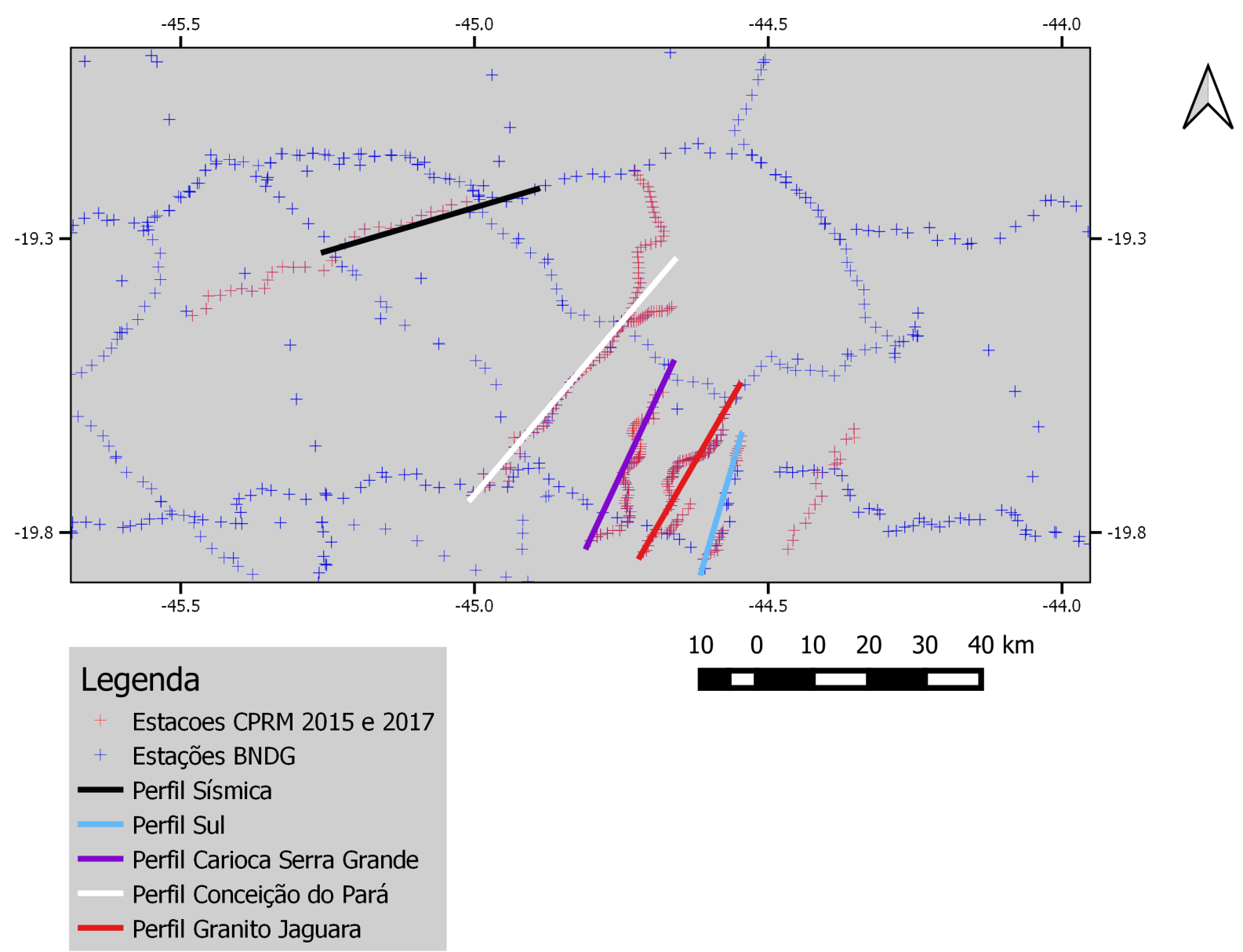

Figura 2.5: Distribuição das estações gravimétricas na área de estudo. As linhas representam os perfis aonde as estações foram rebatidas.

As estações gravimétricas da CPRM foram coletadas em forma de perfis transversais às principais estruturas geológicas de interesse. O espaçamento entre as estações varia, aproximadamente, de $500 \mathrm{~m}$ até $2 \mathrm{~km}$. Seu posicionamento ficou limitado às estradas principais e vicinais da área devido à topografia irregular da região, que impede perfis lineares. No levantamento foi utilizado o gravímetro diferencial CG5 Autograv Gravity Meter da empresa Scintrex e um par de GPS, modelo Hiper SR da empresa Topcon. Um GPS foi utilizado como base, enquanto o outro foi utilizado no modo itinerante acompanhando o gravímetro. A distância entre o GPS base e o móvel não ultrapassou $40 \mathrm{~km}$. 


\subsection{Métodos}

\subsubsection{Inversão do vetor de magnetização (MVI)}

A partir dos dados aeromagnetométricos foi feita a MVI no software Oasis Montaj da Geosoft. Ellis et al. (2012) desenvolveram a técnica com o intuito de uma melhor inversão sobre áreas com presença de remanência magnética significativa. Na MVI, o cálculo da inversão não assume a direção do vetor magnético, nem faz suposições a respeito da fonte magnética se ela é remanente ou induzida.

A MVI calcula o vetor de magnetização $M(r)$ da equação 2.1.

$$
B\left(r_{j}\right)=\nabla \int_{V} M(r) \cdot \nabla \frac{1}{\left|r-r_{j}\right|} d r^{3}
$$

Em que $B\left(r_{j}\right)$ é o campo magnético no ponto $r_{j}$ resultante de um volume $V$ de magnetização $M(r)$ com centro em $r$.

Ao discretizar $V$ em $N$ subvolumes $v_{k}$ de magnetização $m_{k}$ temos a equação 2.2 .

$$
B_{\beta}\left(r_{j}\right)=\sum_{k, \alpha}^{N, 3} m_{k, \alpha} \int_{v_{k}} \partial_{\alpha} \partial_{\beta} \frac{1}{\left|r-r_{j}\right|} d r^{3}
$$

A equação 2.2 define o problema direto da MVI. Portanto, a inversão resolve a magnetização $m_{k}$ de um corpo de volume $v_{k}$ dado um campo magnético $B$. O regularizador utilizado é o mínimo gradiente de Tikonov.

Foram escolhidas duas áreas para calcular a inversão. O resultado utilizado das inversões são blocos 3D da amplitude do vetor de magnetização (susceptibilidade magnética aparente). Destes blocos foram tiradas seções sobre a localização dos perfis. Essas seções foram utilizadas para auxiliar na modelagem direta gravimétrica 2D.

\subsubsection{Processamento dos dados GPS}

O processamento dos dados de posicionamento horizontal e vertical do GPS foi realizado seguindo as seguintes etapas:

- Processamento por ponto preciso, feito online no programa disponibilizado pelo Instituto Brasileiro de Geografia e Estatística (IBGE);

- Processamento dos dados do GPS base e móvel, no software Magnet Tools, para a correção dos pontos adquiridos com o GPS móvel; 
- Nos casos onde precisão no processamento do eixo z (vertical) foi maior que $50 \mathrm{~cm}$ e a distância entre o ponto e a cidade de Belo Horizonte era menor que 40km, foi utilizada a base dessa cidade junto com a base do GPS diferencial. A base de Belo Horizonte é adquirida e disponibilizada pelo IBGE, o qual utiliza uma antena do tipo ZEPHYR GNSS GEODETIC MODEL 2. No caso do erro continuar maior que 50 cm o ponto foi descartado;

- Transformação da altura geométrica para altura ortométrica usando a correção da altura do elipsoide em relação ao geoide. Esse processamento foi realizado no software MAPGEO2010 versão 1.1 (dados adquiridos em 2015) e MAPGEO2015 versão 1.0 (dados adquiridos em 2017), ambos desenvolvidos pelo IBGE.

\subsubsection{Processamento dos dados gravimétricos}

O processamento dos dados gravimétricos foi realizado no software Oasis Montaj da empresa Geosoft e seguiu as etapas:

- Correção de maré;

- Correção de altura do gravímetro com respeito ao solo;

- Correção da deriva;

- Cálculo da gravidade absoluta;

- Correção da gravidade normal pela fórmula do Geodetic Reference System (GRS1967) (Moritz, 1980);

- Correção Ar livre;

- Correção Bouguer com o valor de densidade média da crosta de $2670 \mathrm{~kg} / \mathrm{m}^{3}$;

- Correção de terreno com os dados de topografia do projeto GLOBE do National Oceanic and Atmospheric Administration (NOAA).

A anomalia Bouguer completa é o resultado após a última etapa, correção de terreno. Este tipo de anomalia leva em consideração as variações laterais de topografia que estão acima ou abaixo do platô de Bouguer melhorando o valor da gravidade do ponto. Como os 
dados do BNDG têm apenas a anomalia Bouguer simples, decidimos não aplicar a correção de terreno.

Após o cálculo da anomalia Bouguer dos dados da CPRM e criação de um único conjunto de dados com coerência interna, estes foram gridados pelo método kriging. O tamanho da célula foi determinado pelo próprio software que utiliza a equação 2.3 .

$$
\frac{1}{4} \sqrt{\frac{\text { Grid Area }}{\text { Number data points }}}
$$

Resultando em um espaçamento entre nós de 1,5 km.

Como a aquisição foi feita em estradas sinuosas, não foi possível visualizar em perfis as estações adquiridas. Para tal foram feitas projeções da posição das estações sobre linhas, que representam os perfis utilizados.

\subsubsection{Modelagem gravimétrica direta 2D}

A modelagem direta 2D foi feita no módulo GMSYS-2D do software Oasis Montaj da Geosoft. Este módulo faz o cálculo dos modelos segundo Talwani (1964) e Talwani et al. (1959). Neste módulo foram inseridos os dados de anomalia Bouguer com as coordenadas projetadas sobre a linha. Após inserir os dados é feita uma modelagem interativa na forma de camadas. Em cada camada é necessário informar a densidade. As camadas são desenhadas para tentar adequar ao máximo a anomalia Bouguer calculada do modelo com os dados observados. O software estende as camadas para o infinito na direção perpendicular ao perfil. É possível no mesmo software carregar e georreferenciar imagens ao fundo do modelo, por exemplo, uma seção sísmica.

No módulo GMSYS é possível fazer inversões/otimizações. Não é recomendável fazer inversões com muitos parâmetros, ela tem maior confiabilidade quanto menor for o número de parâmetros. A inversão faz uma implementação feita pelo Webring (1985) dos algorítimos de Marquardt (1963). Esta ferramenta foi utilizada apenas para estimar a densidade de algumas camadas dos perfis onde não havia informações a respeito da densidade ou era necessário fazer pequenas mudanças nos valores de densidade presentes para melhorar o ajuste às observações.

Foram modelados cinco perfis representados na Figura 2.2. A modelagem foi iniciada com o Perfil Sísmica. A seção sísmica georreferenciada, junto com a estratigrafia do greenstone belt (Marinho et al., 2018) serviram como informações a priori na definição das 
camadas que deveriam estar presentes na modelagem. Para determinar a densidade foram utilizados os dados da Tabela 2.1. quando a litologia era similiar. Após modelar com estas densidades e seguindo os refletores da sísmica, quando presentes, a densidade foi recalculada pela função de inversão/otimização do programa. Na ausência de refletores sísmicos, a modelagem foi feita com as informações geológicas de estratigrafia.

A geometria da calha resultante do modelo da sísmica, assim como as densidades definidas serviram como informação a priori para os outros perfis. A estratigrafia, com exceção dos casos em que havia uma nova informação, foi aplicada igualmente para todos os modelos. Foram utilizadas informações da geologia de superfície para que as camadas aflorantes do modelo fossem compatíveis com o mapa geológico.

Em alguns perfis foi necessário introduzir litologias não esperadas, que foram analisadas caso a caso. A densidade de intrusões graníticas, por exemplo, foi definida com valores de densidade próxima aos embasamentos da calha. Pequenas variações foram necessárias para que o modelo ajustesse melhor as observações.

As seções da MVI foram utilizadas em todos os perfis modelados com exceção do perfil Sísmica, no qual foi utilizada a seção sísmica. Como as seções foram retiradas exatamente sobre os perfis, elas foram georreferenciadas no software da mesma maneira que a seção sísmica. Em alguns casos a seção não tinha a mesma extensão do perfil, portanto, apenas uma parte do perfil contém a seção da inversão.

\subsubsection{Limites laterais do greenstone belt}

A partir dos modelos gravimétricos 2D, os valores de anomalia Bouguer referentes às bordas do modelo final do greenstone belt foram tabelados. Analisando esta tabela, foram calculadas curvas de isovalor da anomalia Bouguer para estimar os limites laterais do greenstone belt. Cada curva foi avaliada para checar a compatibilidade com os limites geológicos em superfície e inferidos em sub-superfície. 
Capítulo 3

\section{Resultados}

\subsection{Mapas gravimétrico e magnetométrico}

Nesta seção apresentaremos os mapas gravimétrico e magnetométrico obtidos com os dados disponíveis.

A partir das estações gravimétricas disponibilizadas pelo BNDG e as novas estações adquiridas pela CPRM foi feito o mapa da anomalia Bouguer simples apresentado na Figura 3.1. Este mapa foi feito via krigagem dos dados e tem um espaçamento entre nós de 1,5 km. Nesta imagem também temos a localização das estações gravimétricas utilizadas, dos perfis modelados e do Supergrupo Rio das Velhas segundo o mapa geológico de Minas Gerais (Pinto et al., 2014).

Pelo mapa Bouguer nota-se que a região de estudo se caracteriza por um alto gravimétrico alojado em uma região de transição entre um forte baixo gravimétrico a oeste, com anomalias da ordem de $-115 \mathrm{mGal}$, e alto gravimétrico a leste, com anomalias da ordem de -90 mGal. O alto sobre o Supergrupo Rio das Velhas varia entre, aproximadamente, -93 mGal até valores da ordem de -75 mGal. A região no entorno tem anomalias menores que -95 mGal. Note que o alto gravimétrico apresenta comportamento diferenciado a noroeste e sudeste do Supergrupo Rio das Velhas. A sudeste ele parece terminar abruptamente muito próximo onde o alto gravimétrico leste começa, entre os perfis Jaguara e Sul, enquanto que a noroeste ele continua até o Perfil Sísmica, em preto, em valores da ordem de $-85 \mathrm{mGal}$. 

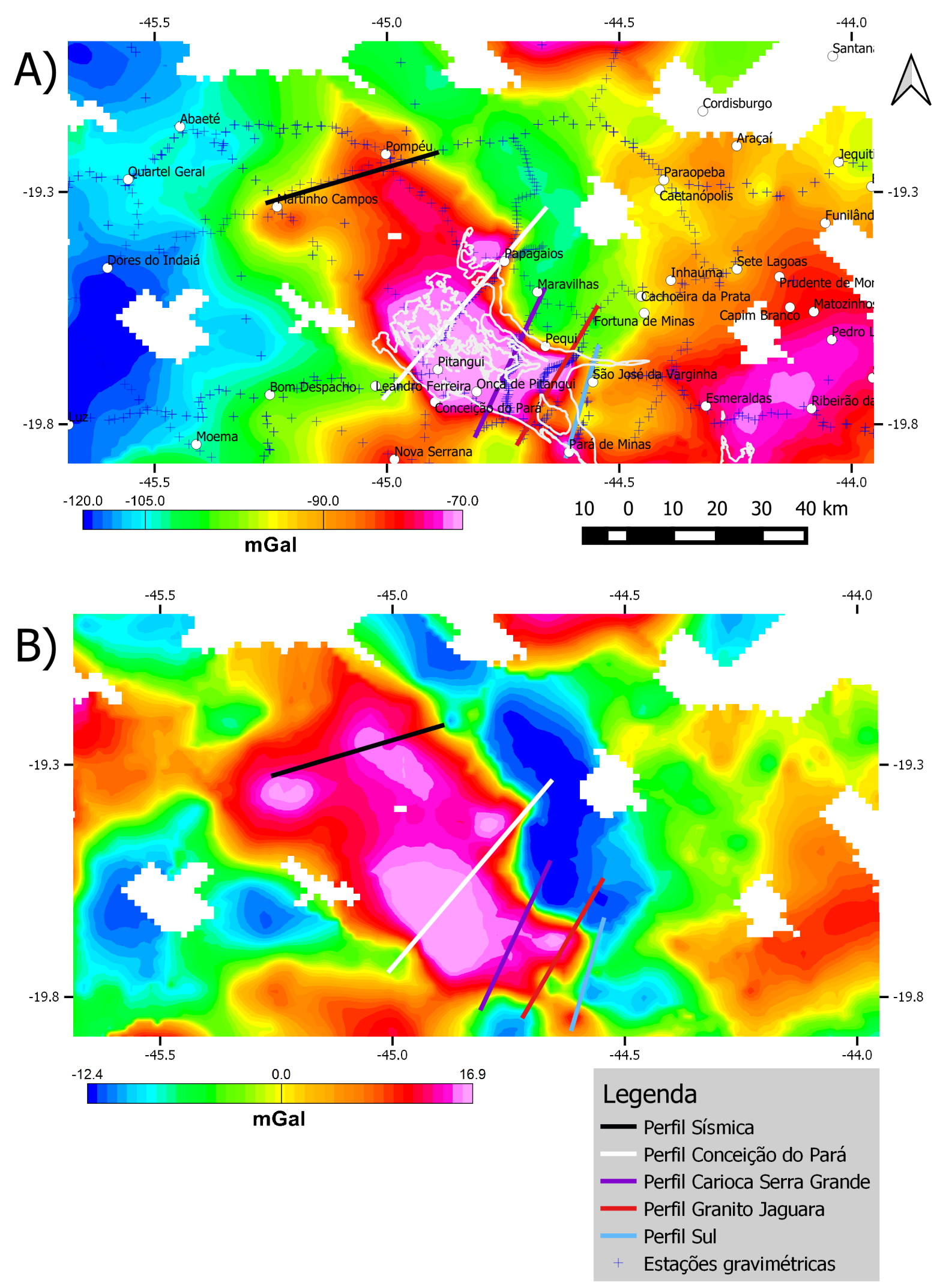

Figura 3.1: A) Mapa da anomalia Bouguer com as estações gravimétricas e a localização dos perfis. O Supergrupo Rio das Velhas está representado pelo contorno em branco. B) Mapa residual da anomalia Bouguer, após a retirada de um regional de ordem 3. 
Para remover uma tendência de $\mathrm{W}$ para $\mathrm{E}$, onde a $\mathrm{W}$ tem-se valores mais baixos e a $\mathrm{E}$ valores mais altos de anomalia Bouguer, foi realizada uma separação regional-residual por ajuste polinomial de grau 3. A anomalia Bouguer observada, na Figura 3.1b, ressalta o alto correspondente ao GP. Como a anomalia Bouguer não parece ser afetada pela remoção do polinômio de grau 3, nem por outros graus mais baixos, testados mas não mostrados aqui, optou-se por modelar o greenstone belt usando a anomalia Bouguer sem remoção do regional. Outro motivo que apoiou a escolha foi a má distribuição dos dados na área, como pode ser visto na Figura 3.1 . Outras técnicas de separação regional-residual não foram testadas em função da má distribuição de dados.

A partir dos aerolevantamentos magnetométricos foi feito o mapa do campo magnético anômalo (Figura 3.2). Este mapa foi feito via gridagem bi-direcional com espaçamento entre nós de $125 \mathrm{~m}$. Junto ao campo magnético estão representados os perfis gravimétricos. Estes perfis passam sobre duas grandes anomalias magnéticas. Uma delas se encontra na porção SW do perfil Conceição do Pará e apresenta uma remanência com caráter de anomalia do hemisfério Norte ou mesmo do equador magnético. O padrão de equador magnético não está claro devido uma possível influência na porção Norte de um outro dipolo, portanto, essa anomalia também pode ser interpretada como dois dipolos. A outra anomalia é cortada pelos perfis Carioca Serra Grande, Granito Jaguara e Sul. Esta anomalia apresenta remanência, neste caso com um caráter de anomalia do hemisfério Norte. 


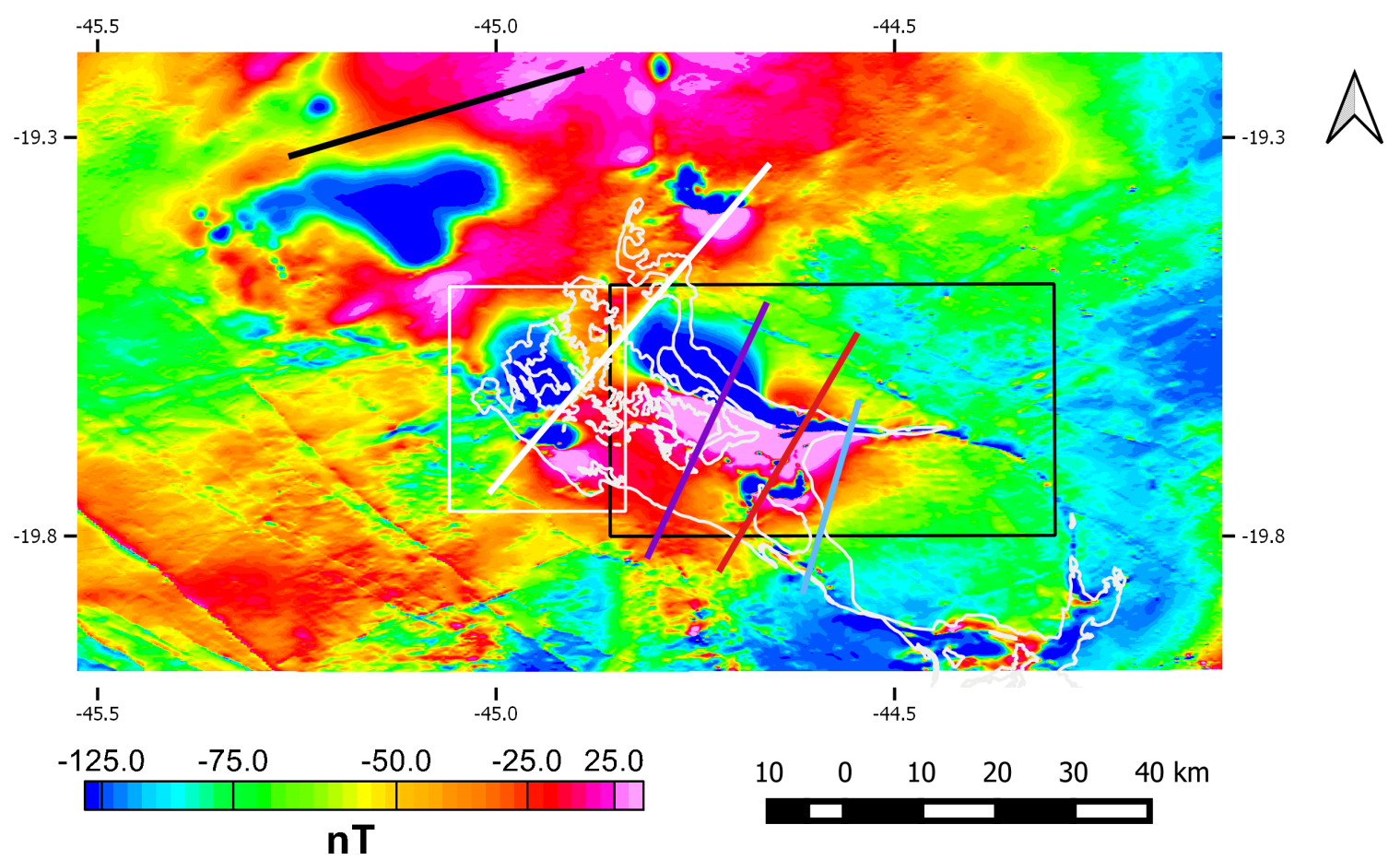

\section{Legenda \\ - Perfil Sísmica \\ Perfil Conceição do Pará \\ - Perfil Carioca Serra Grande \\ - Perfil Granito Jaguara \\ Perfil Sul \\ Área Serra Pequi Jaguara \\ Área Campo Grande Pequi}

Figura 3.2: Mapa do campo magnético anômalo com os perfis gravimétricos e as áreas escolhidas para a inversão. O retângulo em branco corresponde a área Campo Grande Pitangui e o preto à área Serra Pequi Jaguara. O Supergrupo Rio das Velhas está representado pelo contorno em branco. 

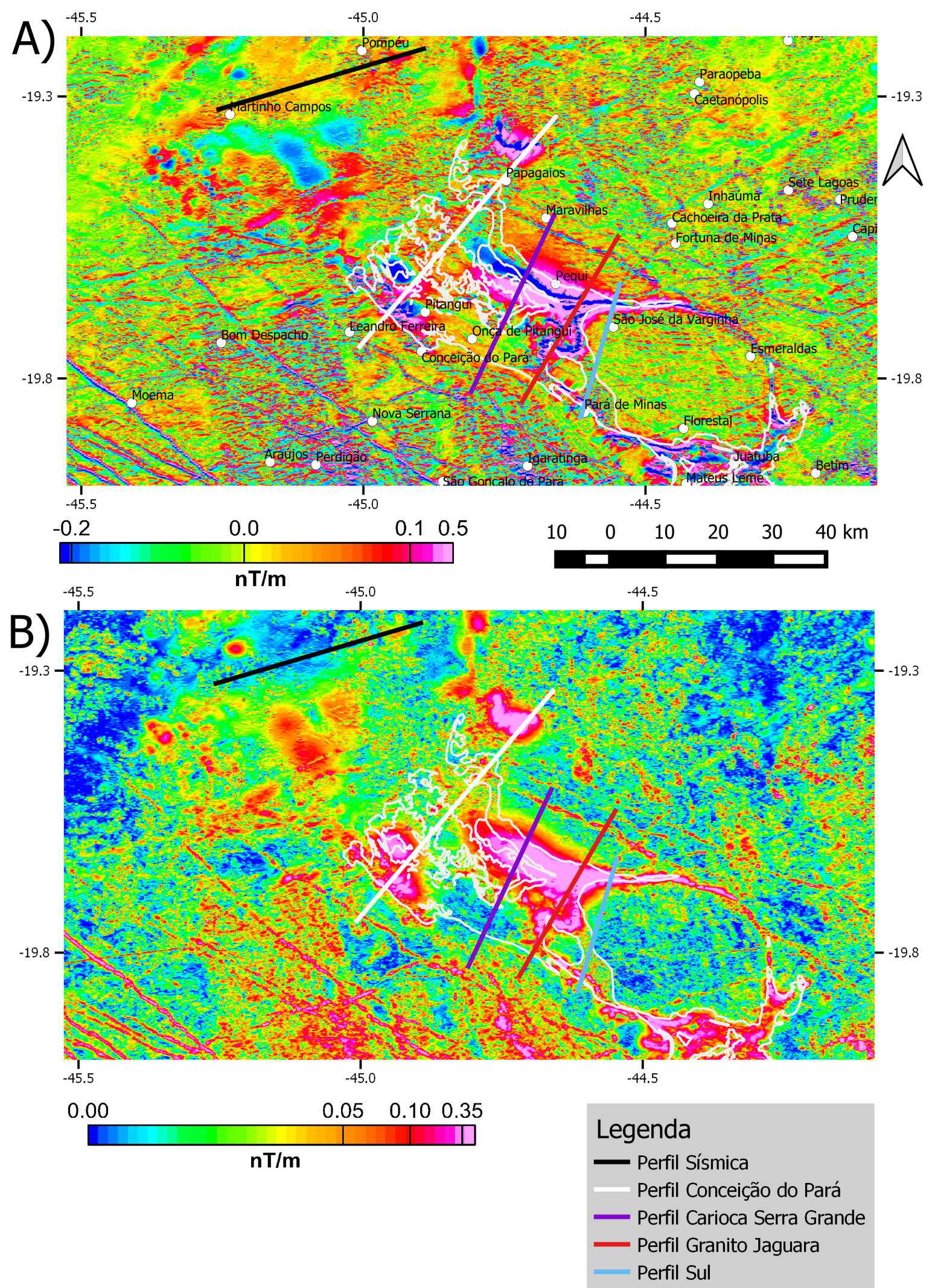

Figura 3.3: (a) Mapa da primeira derivada vertical. (b) Mapa da amplitude do sinal analítico (ASA). 
As Figuras 3.3a e 3.3b apresentam os mapas da primeira derivada vertical e da amplitude do sinal analítico (ASA), respectivamente. Os mapas foram calculados conforme Blakely (1996). Observe que os mapas ressaltam as anomalias nas porções central e sul do Greenstone Belt de Pitangui e duas anomalias nos extremos SW e NE do Perfil Conceição do Pará. Observe (Figuras 3.3 a e 3.3b) como o granitoide Florestal (Figura 2.2 é envolvido por anomalias magnéticas na sua borda mas não apresenta magnetização no seu interior. Os mapas também ressaltam os lineamentos magnéticos na direção NW-SE, mesma direção da calha do GP. Os lineamentos não cortam a calha nem o Granitóide Florestal.

\subsection{Inversão do vetor magnetização (MVI)}

A partir do mapa do campo magnético anômalo, foram escolhidas duas áreas para o cálculo da MVI, representadas na Figura 3.2. A primeira área está representada por um retângulo branco por onde passa o perfil Conceição do Pará e será chamada de área Campo Grande-Pitangui. A segunda área está representada pelo retângulo preto por onde passam os perfis Carioca Serra Grande, Granito Jaguara e Sul e será chamada de área Serra Pequi Jaguara.

O resultado da amplitude do vetor de magnetização da MVI da área Campo GrandePitangui está apresentada na Figura 3.4. Na parte superior está o bloco 3D com a susceptibilidade magnética aparente. Deste bloco foi retirada uma superfície de isovalor igual a 0,015 (SI) de susceptibilidade aparente. Esta superfície de isovalor está apresentada abaixo junto com o campo magnético anômalo e a localização do perfil Conceição do Pará. A superfície de isovalor mostra que a inversão calculou a anomalia magnética como dois corpos. 

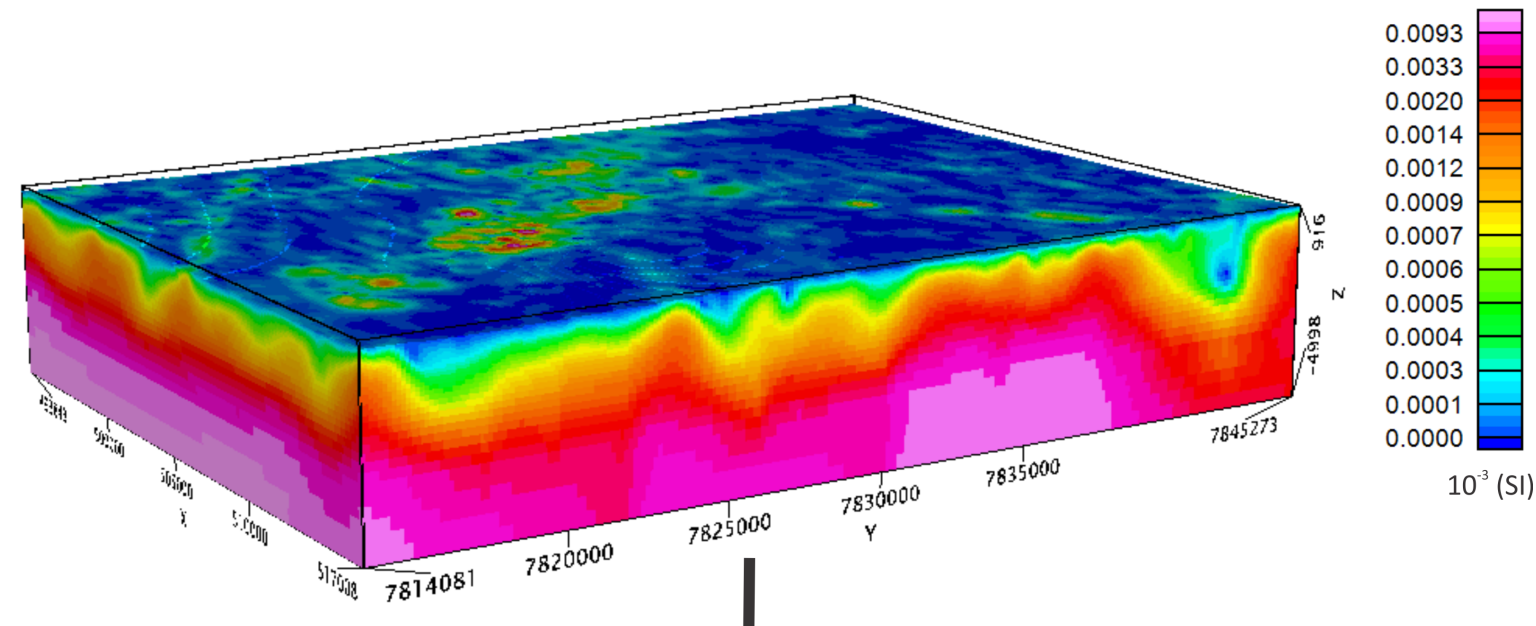

$10^{-3}(\mathrm{SI})$

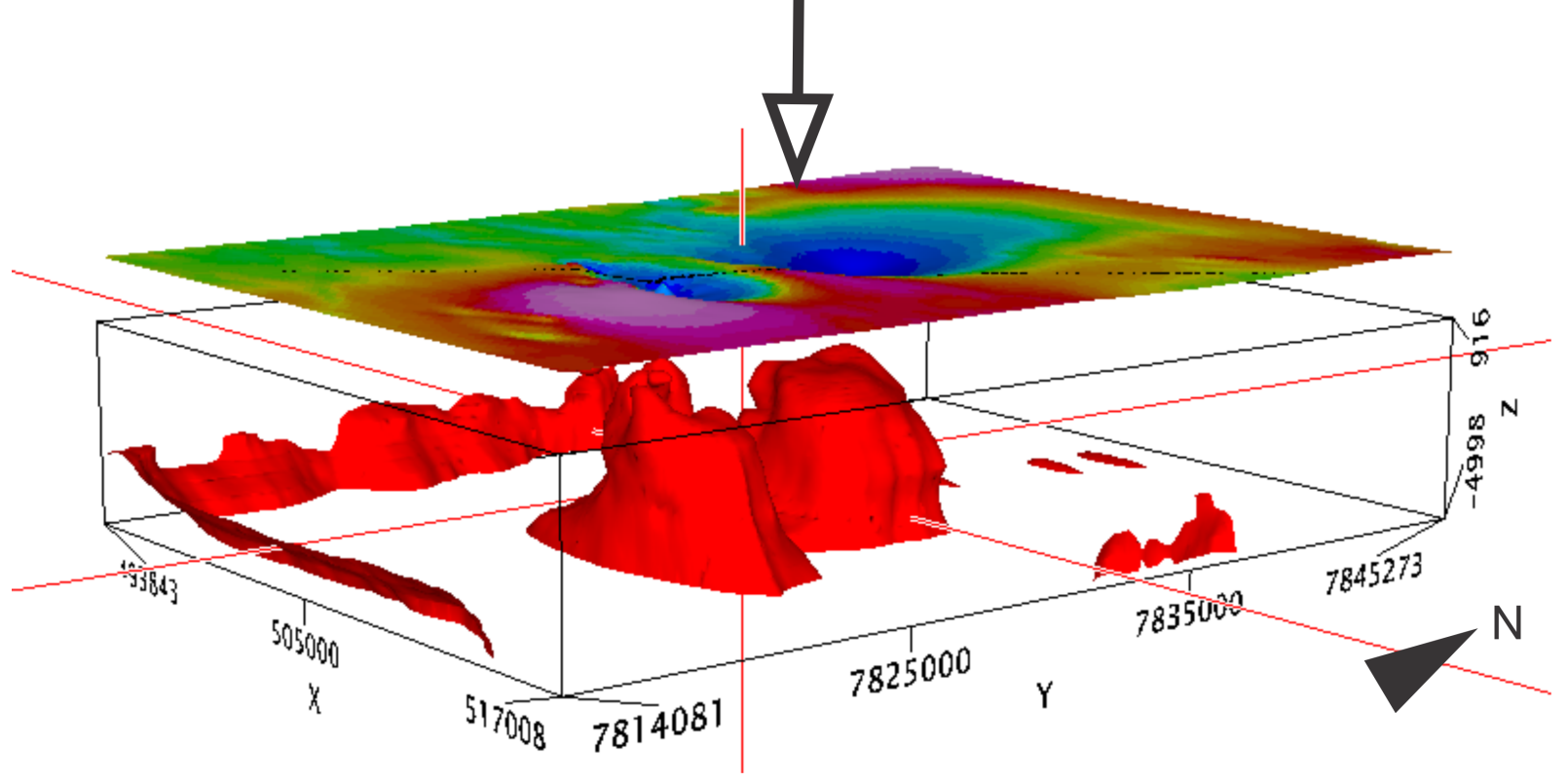

Figura 3.4: Resultado da amplitude do vetor de magnetização da inversão da área Campo Grande Pitangui, delimitada na Figura 3.2. Acima está o bloco 3D de susceptibilidade magnética aparente, abaixo está o mapa do campo magnético anômalo junto com uma isosuperfície de 0,015 (SI) (valor de susceptibilidade magnética aparente).

A MVI referente a área Serra Pequi-Jaguara está representada na Figura 3.5. Acima está o bloco 3D de susceptibilidade magnética resultante da inversão. Abaixo estão a superfície de isovalor correspondente a 0,02 (SI) (susceptibilidade magnética aparente), o campo magnético anômalo e a localização dos perfis Carioca Serra Grande, Granito Jaguara e Sul. A superfície de isovalor mostra um grande corpo que acompanha o centro da anomalia magnética e está presente abaixo de todos os perfis gravimétricos. 


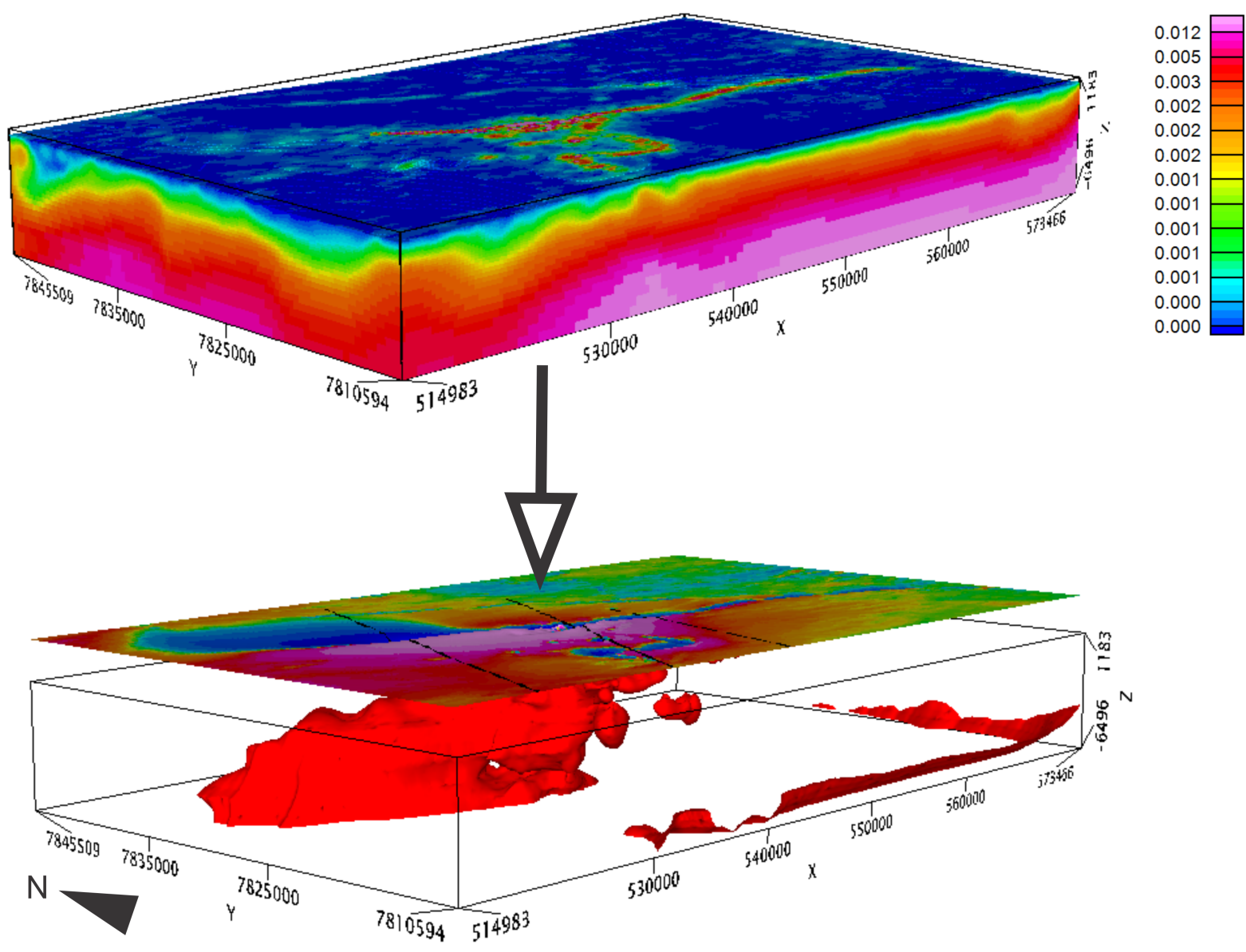

Figura 3.5: Resultado da inversão da área Serra-Pequi Jaguara delimitada na Figura 3.2 Acima está o bloco 3D de susceptibilidade magnética aparente, abaixo está o mapa do campo magnético anômalo junto com uma isosuperfície de 0,02 (SI) (valor de susceptibilidade magnética aparente).

\subsection{Modelo direto gravimétrico $2 D$}

Nesta seção apresentaremos os resultados da modelagem direta dos dados de gravimetria. A modelagem foi feita usando perfis lineares a partir da projeção dos dados gravimétricos coletados, Figura 2.5. Dados de sísmica e das sessões de susceptibilidade aparente obtido da MVI, informações de geologia da superfície e de propriedades físicas de rochas em localidades próximas serviram como vínculos na modelagem. Os perfis foram modelados utilizando a anomalia Bouguer obtida. Para o modelo optou-se por utilizar um valor constante, conhecido como nível de referência de modelagem, para cada perfil. Os valores do nível de referência de cada perfil encontram-se nas legendas das figuras. Podemos observar que os valores variam pouco. Os perfis Sísmica, Conceição do Pará e Carioca 
Serra Grande, tiveram um nível médio de -90,2 mGal, enquanto que os perfis mais a SE, Granito Jaguará e Sul, tem um valor médio de -86,3 mGal para o nível de referência.

No geral, as seções apresentadas nas Figuras 3.6 a 3.10 têm na porção superior, a anomalia Bouguer, medida e projetada sobre o perfil, e a reposta gravimétrica do modelo, pontos pretos e curva laranja, respectivamente. Abaixo, os prismas do modelo com suas respectivas cores e densidade $\left(\mathrm{em} \mathrm{kg} / \mathrm{m}^{3}\right)$. A legenda das litologias encontradas e inferidas na área, representadas pelas diferentes cores do modelo gravimétrico-geológico, está ao final da Figura 3.6 e foi utilizada nos modelos de todos os perfis.

Perfil Sísmica $\left(\left(-19,3^{\circ} ;-45,3^{\circ}\right)\right.$ e $\left.\left(-19,2^{\circ} ;-44,9^{\circ}\right)\right)$ :

Na Figura 3.6 temos o modelo em subsuperfície, gerado a partir dos dados gravimétricos, para o perfil Sísmica. Ele está localizado próximo às cidades de Martinho Campos e Pompéu, tem uma extensão um pouco maior que 40 quilômetros, sua localização na Figura 3.1 está marcada pela linha preta. Ela é coincidente com parte da sísmica publicada por Reis et al. (2017).

Como não possuímos os dados da aquisição sísmica não foi possível fazer um modelo de velocidade para o perfil Sísmica. No entanto, foi feita uma estimativa de velocidade das ondas P com o uso da Tabela 2.1, para uma conversão de velocidade aproximada, visto que a metodologia não é a mais adequada. Nesta tabela as rochas mais representativas do GP são os metabasaltos (sigla MAN na tabela), equivalente às rochas máficas do modelo, e as metavulconoclásticas (sigla XS da tabela), equivalente às rochas metassedimentares do modelo. A MAN possui velocidade das ondas $\mathrm{P}$ de $6,3 \mathrm{~km} / \mathrm{s}$ e a XS de $6,8 \mathrm{~km} / \mathrm{s}$. Foi considerado que $1 / 3$ do GP é preenchido pelas metassedimentares e os outros $2 / 3$ pelas metavulcanoclásticas. A velocidade do Grupo Bambuí que cobre o GP nesta porção não está na Tabela 2.1. O Grupo Bambuí é representado pelos refletores sísmicos da Figura 2.4 até, aproximadamente, $0,5 \mathrm{~s}$. A velocidade estimada a partir da sondagem e perfil sísmico publicados por Reis et al. (2017), é igual a $6 \mathrm{~km} / \mathrm{s}$. A média ponderada da velocidade das ondas $\mathrm{P}$, a partir destes dados, é de, aproximadamente, $6,2 \mathrm{~km} / \mathrm{s}$, e foi a velocidade utilizada para a conversão aproximada da sísmica.

A seção sísmica, retirada de Reis et al. (2017), convertida para profundidade encontrase na parte inferior da Figura 3.6. Sobre a sessão sísmica estão as camadas modeladas, em linhas pretas, e seus respectivos valores de densidade. Note que a maior parte dos corpos modelados acima do Sinclinório Pitangui (Reis et al., 2017) encontra correlação 
com a sísmica. Dentro do Sinclinório Pitangui não há refletores nítidos, portanto, as camadas foram delimitadas apenas pela gravimetria. No modelo do Perfil Sísmica a calha do GP tem o formato aproximado de um semigraben, chegando a quase 4,5 km de profundidade, sendo que na base da calha, pela estratigrafia da Figura 2.3, encontram-se as rochas máficas e máficas com lentes ultramáficas (que serão chamadas a partir daqui como rochas ultramáficas) de maior densidade. Na porção intermediária da Figura 3.6 temos o modelo de distribuição de densidade. A calha do greenstone belt foi preenchida com uma camada de máficas com lentes ultramáficas na base, seguida de máficas e rochas metassedimentares. O Grupo Bambuí recobre a calha. A amplitude da anomalia Bouguer sobre o greenstone belt é cerca de $+7 \mathrm{mGal}$. 

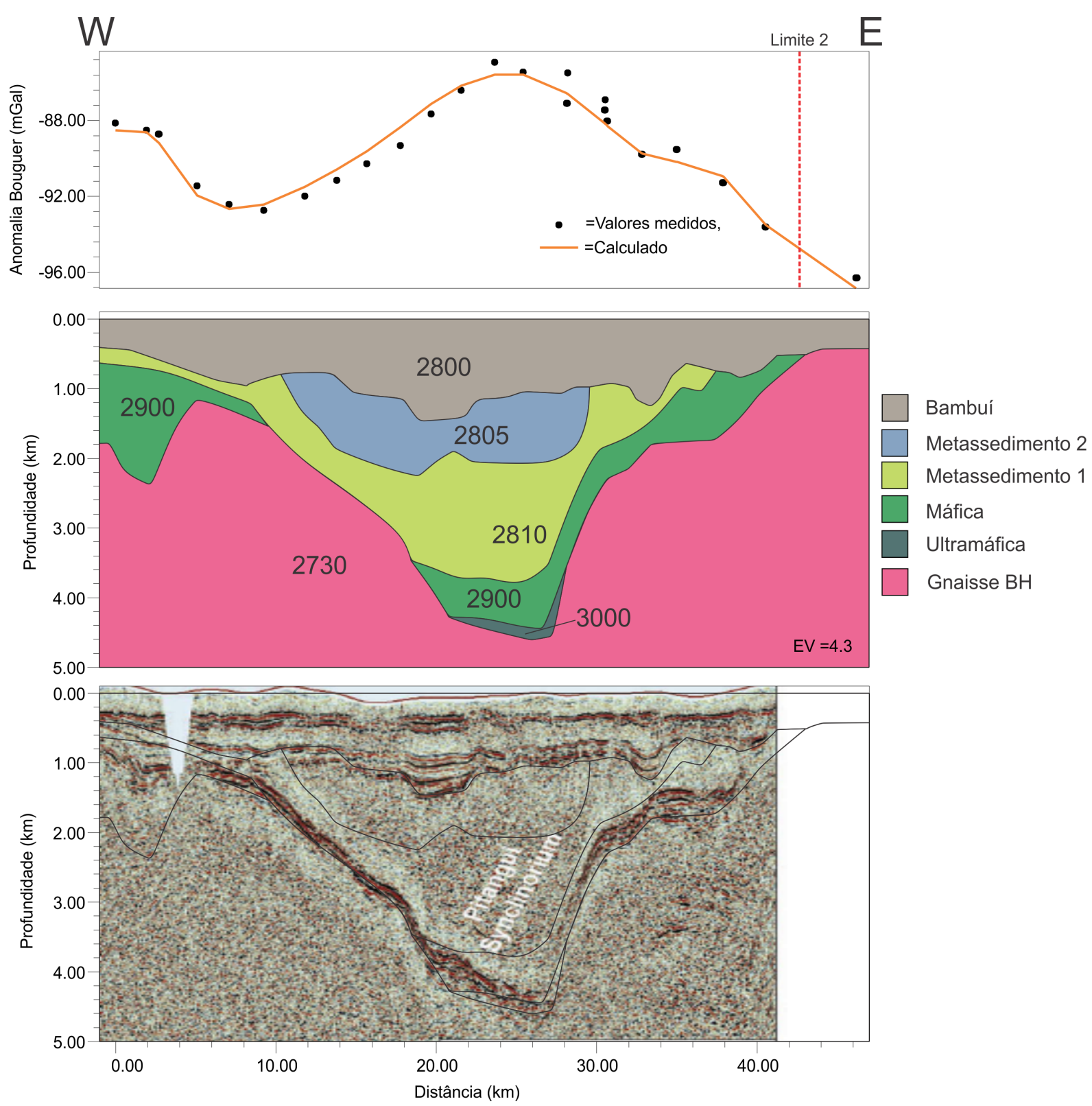

Figura 3.6: Perfil Sísmica modelado. O perfil está localizado entre as coordenadas (latitude, longitude): (-19,3; -45,3) e $(-19,2 ;-44,9)$. Na porção superior estão representados, na forma de pontos, a anomalia Bouguer medida e a curva laranja referente a anomalia gravimétrica calculada pelo modelo. $\mathrm{O}$ nível de referência da modelagem foi de -90,6 mGal. Abaixo, estão representadas as camadas do modelo, com seus respectivos valores de densidade em $\mathrm{kg} / \mathrm{m}^{3}$, e sua legenda de cores ao lado. Abaixo do modelo está a seção sísmica, já convertida em profundidade, junto com as camadas modeladas em linhas pretas. O exagero vertical (EV) é de 4,3X.

Perfil Conceição do Pará $\left(\left(-19,7^{\circ} ;-45,0^{\circ}\right)\right.$ e $\left.\left(-19,3^{\circ} ;-44,6^{\circ}\right)\right):$

Na Figura 3.7 temos o modelo em profundidade para o Perfil Conceição do Pará. O início do perfil se encontra próximo à cidade de Leandro Ferreira e o final próximo à 
cidade de Papagaios, sua extensão é de, aproximadamente, 55 quilômetros e é o maior perfil modelado. A localização do perfil está representada pela linha branca na Figura 3.1 .

Nesta seção, o GP aflora em alguns trechos, a calha é mais aberta e ainda apresenta uma base em profundidades da ordem de 4,5 km, como no Perfil Sísmica. A sequência das rochas foi mantida, com um significativo aumento da espessura das rochas máficas. A amplitude da anomalia Bouguer sobre o GP é, aproximadamente, +18 mGal.

A seção da MVI foi retirada sobre o perfil da inversão correspondente a área Campo Grande Pitangui da Figura 3.2. Essa seção mostra duas grandes anomalias, de alta susceptibilidade magnética, verticalizadas. Estas duas anomalias correspondem ao resultado visto na Figura 3.4, que a inversão considera como anomalia magnética de dois corpos.

Perfil Carioca Serra Grande ((-19,8 ; -44, $\left.8^{\circ}\right)$ e $\left.\left(-19,5^{\circ} ;-44,7^{\circ}\right)\right)$ :

O perfil modelado Carioca Serra Grande (Figura 3.8) começa próximo à cidade Onça de Pitangui e termina próximo da cidade de Maravilhas. Tem uma extensão aproximada de 35 quilômetros. É o perfil representado por uma linha roxa na Figura 3.1

O resultado do modelo mostra que a profundidade da calha começa a diminuir, na média encontra-se em torno de $3,5 \mathrm{~km}$, a seção transversal também é menor, diminui de cerca $50 \mathrm{~km}$ no Perfil Conceição do Pará para cerca de $20 \mathrm{~km}$ neste perfil. Como nos outros perfis as rochas mais densas formam o substrato da calha. Neste perfil a sequência de metassedimentos (verde claro) sofre um afinamento e as rochas máficas continuam espessas como no modelo Conceição do Pará. A anomalia Bouguer sobre o GP é de, aproximadamente, $+12 \mathrm{mGal}$.

A seção da MVI deste modelo e das próximas modelagens apresentadas correspondem à área Serra Pequi Jaguara (Figura 3.2. A seção mostra uma grande anomalia verticalizada na porção a NE que corresponde à região de alta susceptibilidade magnética apresentada na superfície de isovalor da Figura 3.5. O perfil é perpendicular a esta região de alta susceptibilidade magnética e, na seção, mostra a espessura desta região. 


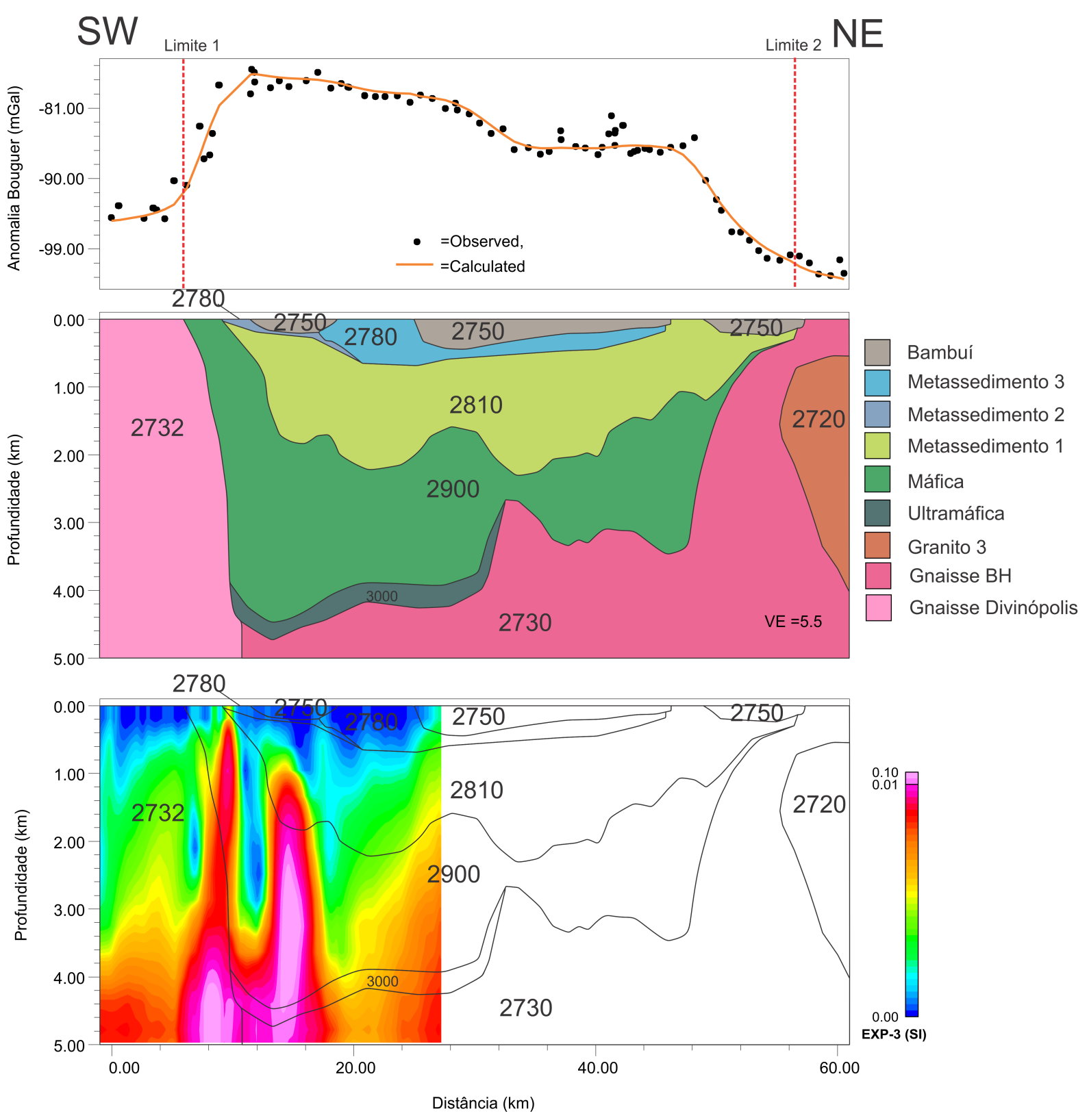

Figura 3.7: Perfil modelado Conceição do Pará. O perfil está localizado entre as coordenadas (latitude, longitude): $(-19,7 ;-45,0)$ e $(-19,3 ;-44,6)$. A porção superior se refere aos valores de anomalia Bouguer medidos, pontos pretos, e à resposta do modelo, linha laranja. O nível de referência da modelagem foi de -89,9 mGal. Ao meio estão representadas as camadas do modelo, com seus respectivos valores de densidade em $\mathrm{kg} / \mathrm{m}^{3}$. Na porção inferior estão representadas as camadas modeladas em linha preta junto com a seção da MVI ao fundo. 

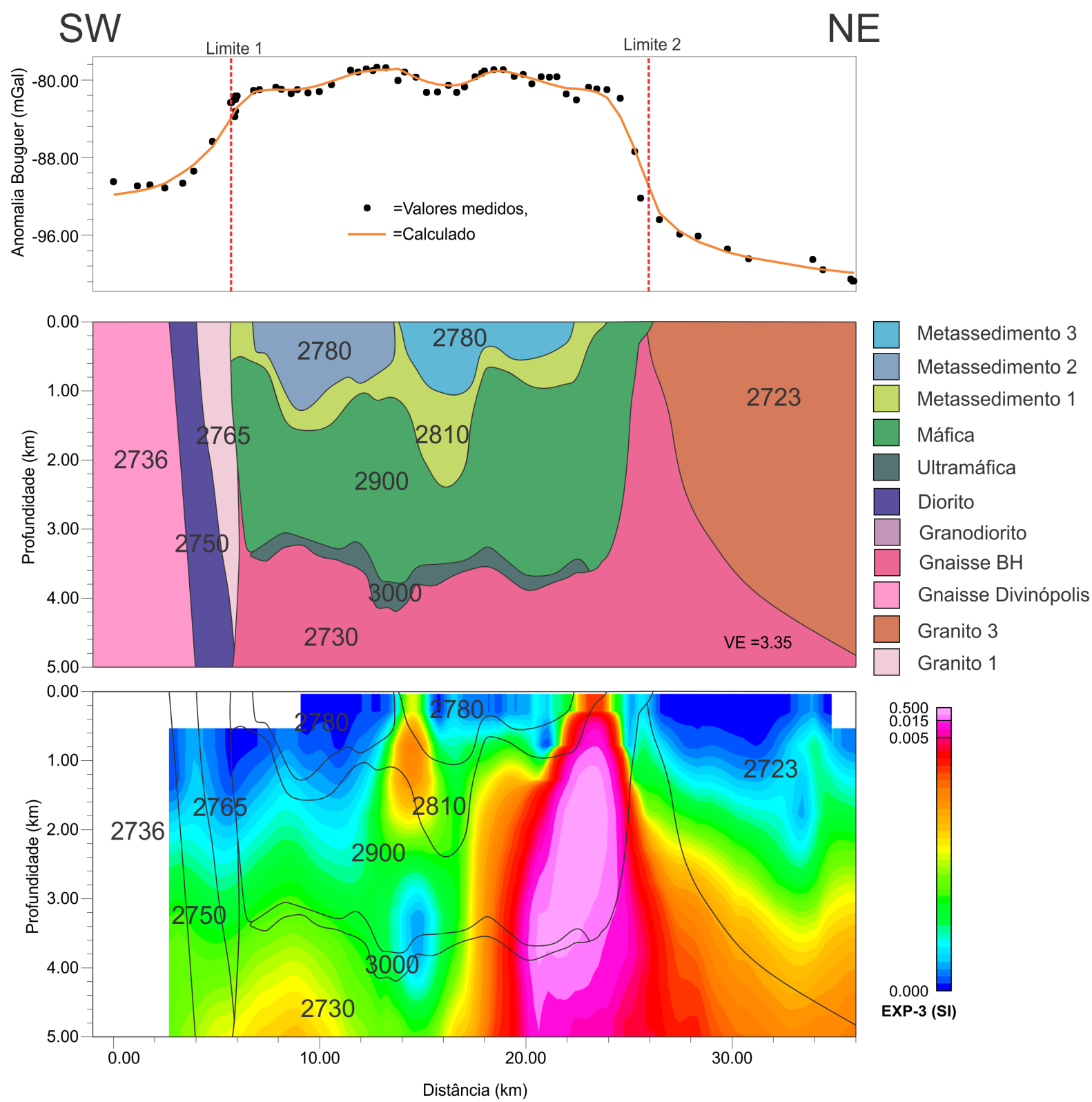

Figura 3.8: Perfil modelado Carioca Serra Grande. O perfil está localizado entre as coordenadas (latitude, longitude): $(-19,8 ;-44,8)$ e $(-19,5 ;-44,7)$. A porção superior se refere aos valores de anomalia Bouguer medidos, pontos pretos, e à resposta do modelo, linha laranja. O nível de referência da modelagem foi de -90,0 mGal. Ao meio estão representadas as camadas do modelo, com seus respectivos valores de densidade em $\mathrm{kg} / \mathrm{m}^{3}$. Na porção inferior estão representadas as camadas modeladas em linha preta junto com a seção da MVI ao fundo.

\section{Perfil Granito Jaguara $\left(\left(-19,8^{\circ} ;-44,7^{\circ}\right)\right.$ e $\left.\left(-19,5^{\circ} ;-44,5^{\circ}\right)\right)$ :}

O modelo do perfil Granito Jaguara está apresentado na Figura 3.9. Este perfil passa próximo à cidade de Pequi e tem uma extensão de, aproximadamente, 35 quilômetros. A sua localização está representada pela linha vermelha da Figura 3.1. 
A calha, no modelo apresentado, é dividida em duas, uma menor à SW da intrusão granítica mapeada em superfície (granito 2, em laranja) com uma assinatura na anomalia Bouguer de, aproximadamente, +5 mGal e outra maior, com amplitude de +15 mGal, à NE da intrusão granítica. A calha é menor, em extensão (cerca de 2,5 km) e profundidade $(1,5 \mathrm{~km})$, do que nos perfis anteriores e nota-se um volume comparativamente maior de rochas máficas. Na porção SW do perfil, foi modelada uma inversão na sequência das rochas, sendo a base formada pelas rochas máficas e sobre estas encontram-se as rochas ultramáficas. Isso ocorre pois no mapeamento foi observada uma maior concentração de lentes ultramáficas, o que não implica em uma inversão real das camadas.

A seção MVI é, como no perfil Carioca Serra Grande, perpendicular a uma grande região de alta susceptibilidade magnética representada pela superfície de isovalor da Figura 3.5. Porém há uma diferença nesta seção, as regiões magnéticas estão divididas em ao menos duas regiões, que condiz com o mapa do campo magnético anômalo (Figura 3.2), em que é possível ver ao longo deste perfil uma pequena anomalia magnética dentro de uma grande anomalia magnética, indicando a presença de mais de um corpo.

Perfil Sul $\left(\left(-19,9^{\circ} ;-44,6^{\circ}\right)\right.$ e $\left.\left(-19,6^{\circ} ;-44,6^{\circ}\right)\right)$ :

O modelo do Perfil Sul encontra-se na Figura 3.10. Ele começa próximo à cidade de Pará de Minas e termina próximo à cidade de São José da Varginha, linha verde da Figura 3.1. Este perfil tem uma extensão de, aproximadamente, 25 quilômetros, é o menor perfil modelado, o GP aflora em duas porções do perfil, uma de maior extensão à SW com amplitude de +12 mGal e extensão de $5 \mathrm{~km}$ e outra menor, com amplitude de $+5 \mathrm{mGal}$ e extensão menor do que 1,5 km, aproximadamente, à NE. Ambas as calhas são menores em extensão e profundidade do que nos outros perfis. As profundidades não alcançam a 1,2 km. A seção MVI é perpendicular ao mesmo grande corpo presente nos perfil Carioca Serra Grande e Granito Jaguara. Neste caso este corpo está localizado na porção NE, ao final do perfil. 


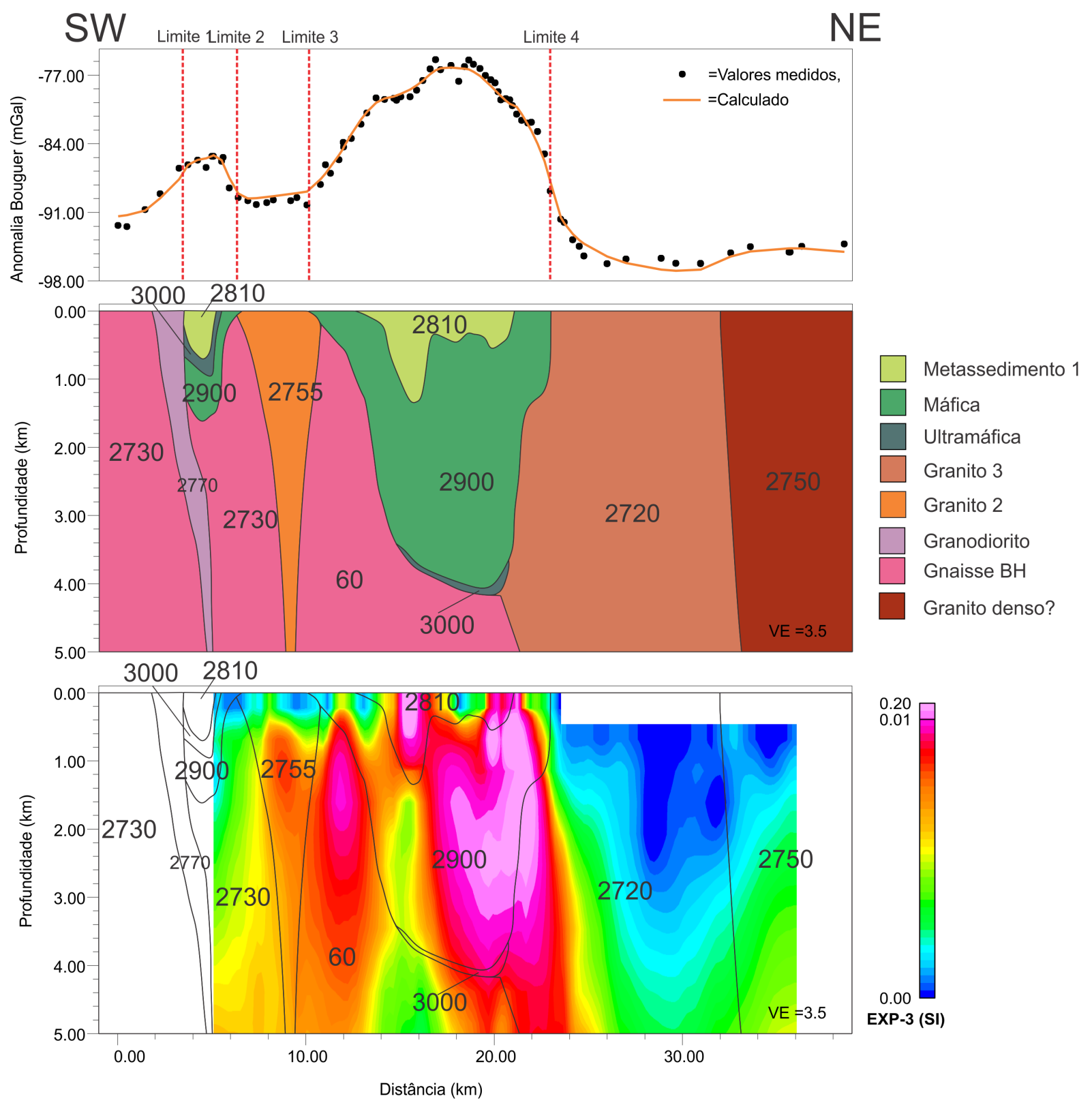

Figura 3.9: Perfil modelado Granito Jaguara. O perfil está localizado entre as coordenadas (latitude, longitude): $(-19,8 ;-44,7)$ e $(-19,5 ;-44,5)$. A porção superior se refere aos valores de anomalia Bouguer medidos, pontos pretos, e à resposta do modelo, linha laranja. O nível de referência da modelagem foi de -85,9 mGal. Ao meio estão representadas as camadas do modelo, com seus respectivos valores de densidade em $\mathrm{kg} / \mathrm{m}^{3}$. Na porção inferior estão representadas as camadas modeladas em linha preta junto com a seção da MVI ao fundo. 


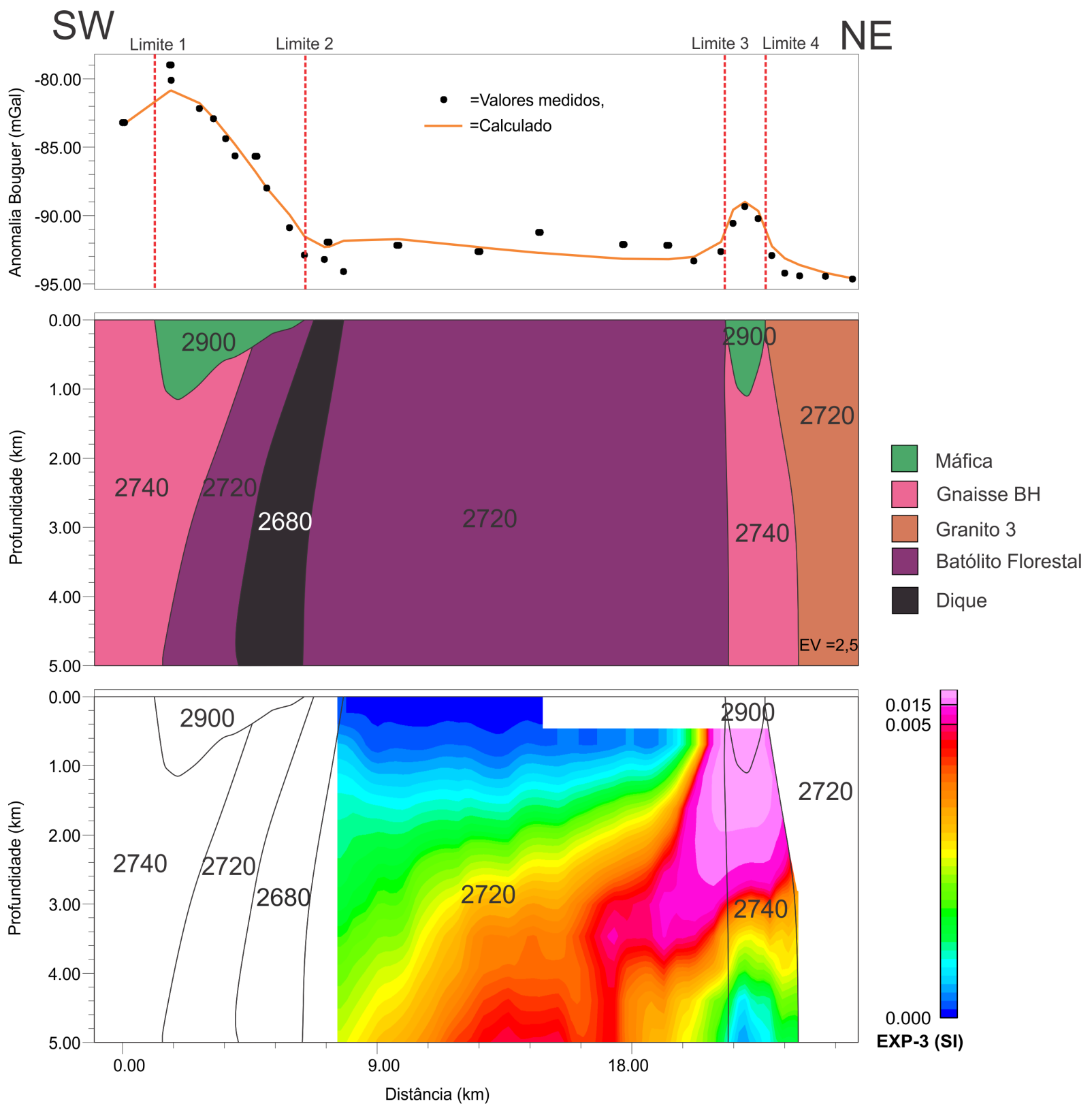

Figura 3.10: Perfil modelado Sul. O perfil está localizado entre as coordenadas (latitude, longitude): $(-19,9 ;-44,6)$ e $(-19,6 ;-44,6)$. A porção superior se refere aos valores de anomalia Bouguer medidos, pontos pretos, e à resposta do modelo, linha laranja. O nível de referência da modelagem foi de -86,8 mGal. As linhas tracejadas vermelhas representam os limites laterais do greenstone belt (1 a 4). Ao meio estão representadas as camadas do modelo, com seus respectivos valores de densidade em $\mathrm{kg} / \mathrm{m}^{3}$. Na porção inferior estão representadas as camadas modeladas em linha preta junto com a seção da MVI ao fundo. 


\subsection{Limites laterais do Greenstone belt}

Dos modelos gravimétricos 2D apresentados foram retirados os valores da anomalia Bouguer referente aos limites inferidos do greenstone belt. Nas Figuras 3.6, 3.7, 3.8, 3.9 e 3.10, as linhas verticais vermelhas tracejadas indicam aonde estão os limites laterais dos perfis. Estes valores estão apresentados na Tabela 3.1 e variam de -100 a -82 mGal.

No perfil Sísmica foi colocado apenas o limite 2 localizado na porção Leste. O limite a Oeste não está presente na modelagem, por esta razão não foi colocado. Os perfis Granito Jaguara e Sul têm 4 limites inferidos porque ambos são modelados como duas calhas.

Tabela 3.1 - Tabela com os valores da anomalia Bouguer dos limites laterais do GP.

\begin{tabular}{|l|r|r|r|r||}
\hline \multirow{2}{*}{ Perfil } & \multicolumn{5}{|c|}{ Limites laterais (mGal) } \\
\cline { 2 - 5 } & Limite 1 & Limite 2 & Limite 3 & Limite 4 \\
\hline Sísmica & & -94 & & \\
\hline Conceição do Pará & -92 & -100 & & \\
\hline Carioca Serra Grande & -84 & -92 & & \\
\hline Granito Jaguara & -87 & -89 & -89 & -88 \\
\hline Sul & -82 & -92 & -92 & -91 \\
\hline
\end{tabular}

Com os valores da tabela foi escolhido um intervalo para estimar o limite lateral do greenstone belt e, então, foi feito um mapa com curvas de isovalor com valores de -93 a $-87 \mathrm{mGal}$ e intervalo de $2 \mathrm{mGal}$ entre as curvas (Figura 3.11. Cada curva tem uma característica diferente, por exemplo, a preta tracejada, de valor -93 mGal mostra uma feição na porção NW que não é indicada por nenhuma outra curva. 


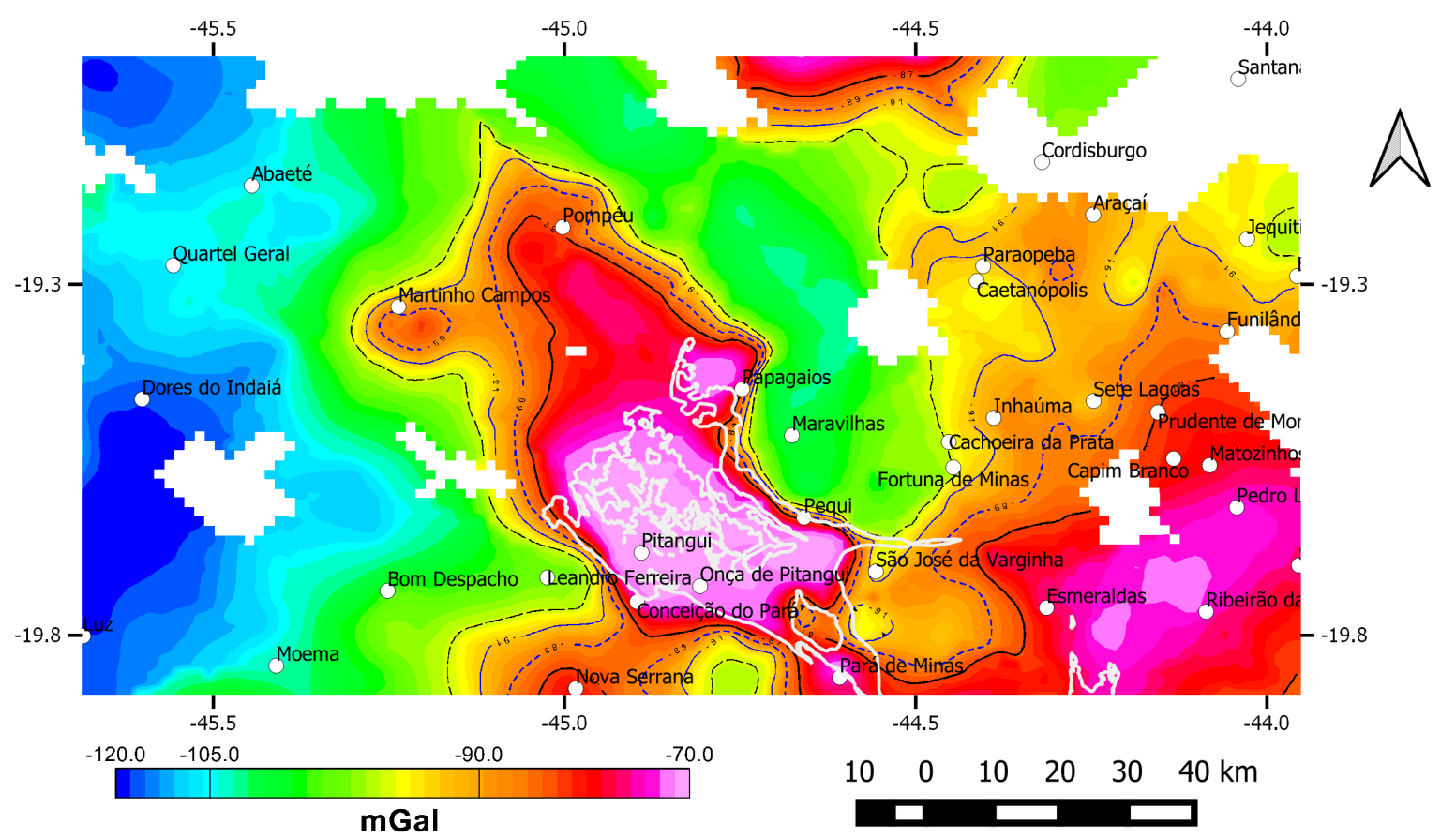

Figura 3.11: Mapa da anomalia Bouguer com curvas de isovalor. Linha preta tracejada corresponde a -93 mGal, azul contínua a -91 mGal, azul tracejada -89 mGal e preta contínua -87 mGal. 
Capítulo 4

\section{Discussão}

Apesar de não ser regra, em todos os exemplos de modelagem gravimétrica em greenstone belt do mundo e do Brasil (Blum et al., 2000; Souza et al., 1992, Baltazar e Raposo, 1993, e as demais referências da introdução), a anomalia Bouguer sobre o greenstone belt é caracterizada por um alto, no GP não é diferente, ele é caracterizado por um contraste positivo de anomalia Bouguer maior que $+10 \mathrm{mGal}$ nas regiões centrais. Este contraste era esperado devido ao GP ser composto por rochas metaígneas, metassedimentares e metavulcanossedimentares que são, em geral, mais densas que as rochas onde o GP está inserido (granitos/gnaisses)

\subsection{Modelos 2D}

Em todas as modelagens gravimétricas, com exceção do perfil Sul, há uma camada de rochas ultramáficas. Essa camada é colocada na base dos modelos, com pequena espessura. Esta rocha é descrita na geologia como máfica com lentes ultramáficas e, normalmente, se encontra próxima a base do GP. Nos modelos Sísmica, Conceição do Pará, Carioca Serra Grande e Granito Jaguará (porção NE) as rochas ultramáficas são apresentadas como uma camada fina abaixo das rochas máficas. Como estas camadas estão a grandes profundidades e são pouco espessas, sua presença é pouco significativa na modelagem gravimétrica. A Figura 4.1 mostra o modelo Conceição do Pará sem a presença das ultramáficas. A diferença entre as curvas verde (resposta do modelo da Figura 3.7) e laranja (resposta do modelo atual) é insignificante. As rochas ultramáficas, posicionadas na base do GP, tornam os modelos condizentes com a estratigrafia descrita no mapa elaborado por Marinho et al. (2018) mas sua presença ou ausência não afeta a anomalia Bouguer calculada. A única 
exceção é o perfil Granito Jaguara (Figura 3.9) onde as rochas ultramáficas são aflorantes na porção SE, próximo da marca de $3 \mathrm{~km}$ do início do perfil.

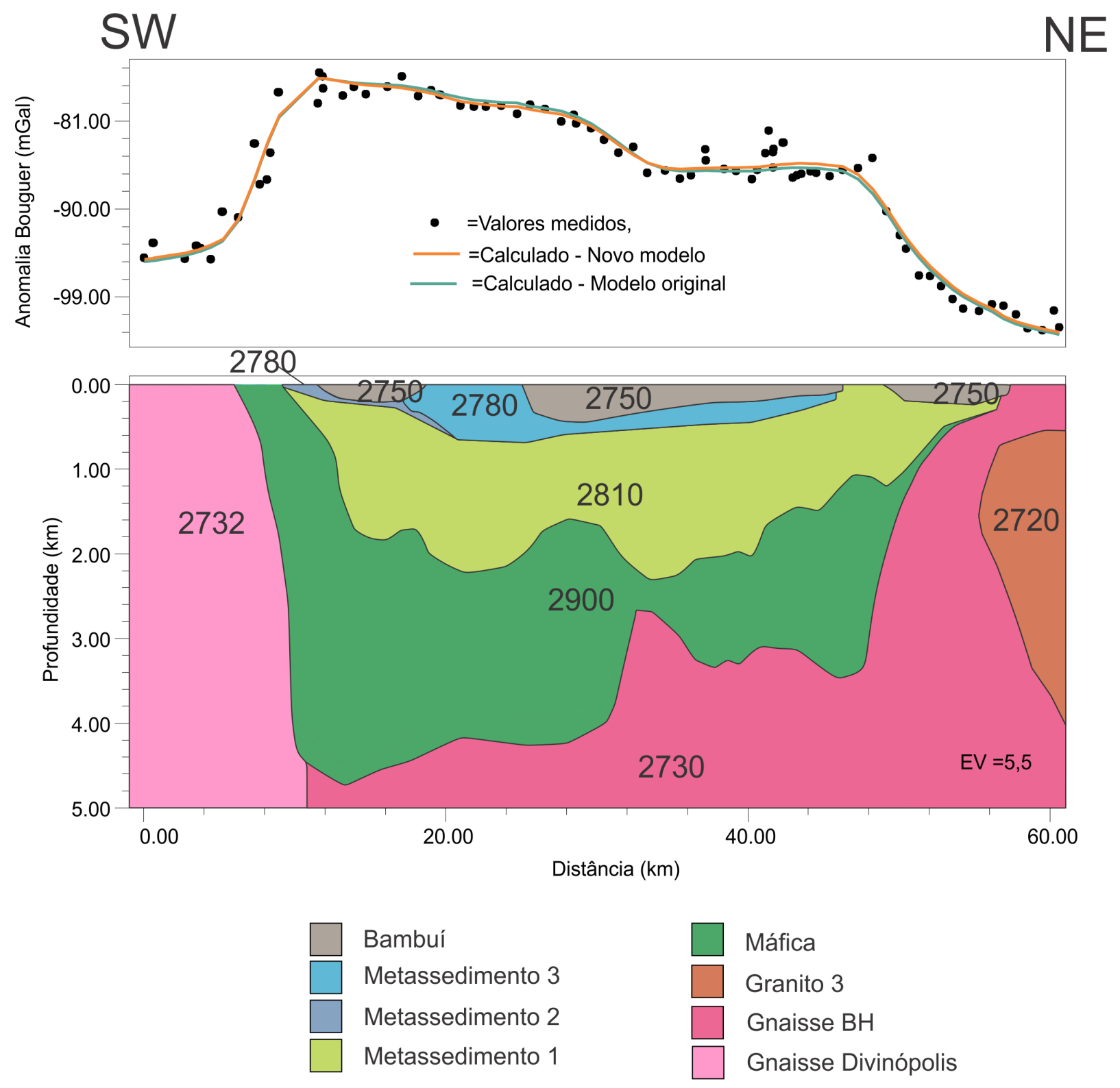

Figura 4.1: Perfil modelado Conceição do Pará sem a presença das rochas ultramáficas. A linha laranja mostra a resposta do novo modelo e a verde do modelo antigo.

A geometria e profundidade do perfil modelado Sísmica (Figura 3.6 foram utilizados como vínculo para os outros perfis. Devido o uso da seção sísmica como vínculo da modelagem, a profundidade do topo do embasamento e da base do Bambuí não podem ser alteradas na modelagem do perfil Sísmica, e elas seguem os refletores da seção. As camadas modeladas como metassedimentos e máficas não estão presentes nos refletores sísmicos. Esse fato pode ser explicado devido a presença de grande quantidade de dobras no greens- 
tone belt, o que faz com que a energia das ondas sísmicas sofram um grande espalhamento, resultando em uma baixa qualidade dos dados (Yilmaz e Doherty, 1987). Apesar do perfil modelado Sísmica não apresentar grandes variações de topografia na camada máfica, a geologia de superfície e os outros modelos indicam a presença delas. O espaçamento maior entre as estações gravimétricas no perfil Sísmica reduz o detalhamento da modelagem, o que pode explicar a ausência de indicativos de dobras neste modelo. Portanto, a presença das rochas metassedimentares e máficas são justificadas pela estratigrafia do GP e não pela sísmica.

Como as camadas de metassedimentos e máficas não apresentam refletores claros na seção sísmica, elas foram modeladas para que o ajuste dos dados medidos fosse o mais próximo da anomalia Bouguer calculada. Pequenas discrepâncias podem ser justificadas por dois fatores: falta dos dados brutos da seção sísmica sendo necessário fazer uma estimativa da velocidade das ondas $\mathrm{P}$ para o pacote como um todo, ao invés de um modelo de velocidade para cada camada; falta de um posicionamento preciso do ponto de início e fim da seção sísmica, esses pontos foram calculados através do georreferenciamento da seção a partir do mapa publicado no artigo, trazendo imprecisões.

A modelagem mostra uma continuidade do GP a oeste, porém essa é a única porção em que a modelagem do embasamento não é condizente com o refletor da sísmica. Essa incompatibilidade pode ser explicada em razão das estações utilizadas nessa porção estarem mais distantes da posição do perfil e localizadas em uma porção a Sul, onde, pelo mapa de anomalia Bouguer (Figura 3.1), há uma possível continuidade do greenstone belt, algo que parece não acontecer na direção do perfil da Sísmica.

O perfil Conceição do Pará (Figura 3.7) é parcialmente recoberto pelo Grupo Bambuí. As densidades utilizadas foram as mesmas do perfil Sísmica. Quando não havia uma camada equivalente ao do perfil Sísmica, a densidade foi estimada para obter um bom ajuste. Este perfil apresentou uma geometria do GP similar à presente na modelagem do perfil Sísmica. A profundidade máxima de ambos os modelos é de, aproximadamente 4,5 km, porém a Sísmica tem uma espessura para o greenstone belt um pouco menor, considerando que o Grupo Bambuí apresenta cerca de 1,5 km de espessura na área. A sísmica apresenta o ponto mais profundo na porção central do perfil, enquanto que no perfil Conceição do Pará o ponto de maior profundidade se encontra deslocado para SW. A camada pertencente às rochas máficas no perfil Conceição do Pará tem grandes variações 
no relevo, que pode ser explicado como dobras, coerentes com a tectônica presente na área.

No extremo NE da modelagem há o aparecimento em subsuperfície de um corpo granítico de densidade de $2720 \mathrm{~kg} / \mathrm{m}^{3}$. Este corpo está presente no mapeamento geológico em uma porção a Sul deste perfil e seu aparecimento na modelagem é justificado pela anomalia Bouguer. A Figura 4.2 mostra como ficaria o perfil sem a presença deste granito. Na porção a NE a resposta do modelo (curva laranja) apresenta valores de anomalia Bouguer superiores aos dados medidos, justificando sua presença.

A seção de susceptibilidade magnética aparente, resultante da MVI, mostra dois grandes corpos magnéticos verticalizados e uma região mais magnética ao final da seção, na porção a NE. Pela geologia da região, é esperado que os corpos magnéticos (grande maioria formada por formações ferríferas bandadas - BIFs) estejam presentes nas máficas e no metassedimento 1 próximo ao contato com as máficas. Estes dois corpos magnéticos são representados pela isosuperfície da Figura 3.4. O corpo magnético vertical localizado a NE fica próximo ao contato entre a máfica e o metassedimento 1, já o corpo a SW não tem boa compatibilidade. Este resultado da inversão pode ser explicado pelas anomalias presentes no mapa do campo magnético anômalo (Figura 3.2), que podem ser interpretadas como dois dipolos na área ou uma anomalia remanente com padrão de equador a sul e outra anomalia remanente com padrão do hemisfério norte na porção norte, onde o baixo desse dipolo influencia o alto da porção norte da anomalia com padrão de equador. Esta segunda hipótese é mais coerente com a geologia de superfície pois teríamos apenas um corpo magnético na região do perfil, mas não condiz com o resultado da inversão.

A região magnética que começa a aparecer na porção NE, da seção da inversão, indica uma elevação de um corpo magnético. Esta resposta pode ser coerente com a modelagem gravimétrica, a qual em uma posição próxima a esta região magnética tem um formato sinformal referente às rochas máficas. Porém como a área da inversão termina ao meio deste corpo magnético, não é possível ter uma boa confiabilidade. 

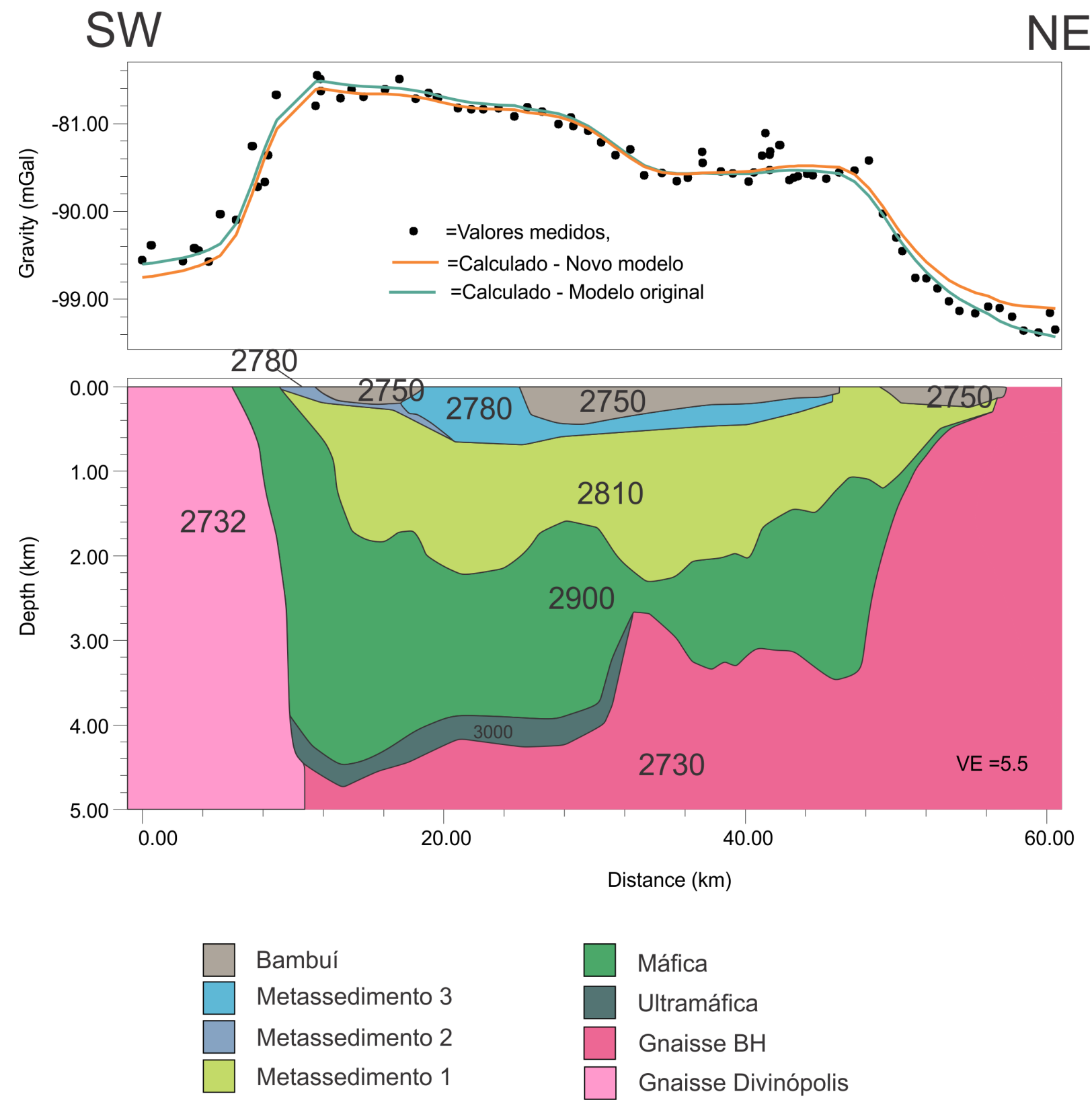

Figura 4.2: Perfil modelado Conceição do Pará sem a presença do granito a NE. A curva em laranja mostra a resposta do modelo novo e a em verde a do modelo antigo.

O perfil Carioca Serra Grande (Figura 3.8) foi modelado com uma profundidade máxima um pouco menor de 4,0 km e pequenas variações no embasamento, que ficou com o ponto mais profundo centrado no GP. Grandes variações ocorrem na parte central do perfil, no topo das rochas máficas e na base do pacote metassedimentar 1. Estas variações ocorrem para justificar um baixo nas observações gravimétricas e também são coerentes com a tectônica. O granito que aparece no perfil Conceição do Pará está presente na porção NE deste perfil e é aflorante, tanto no modelo quanto na geologia de superfície. 
A seção da MVI retirada neste perfil é proveniente da inversão da área Serra Pequi Jaguara, apresentada na Figura 3.5. O perfil Carioca Serra Grande é perpendicular a um grande corpo magnético previsto pela MVI. Na seção este corpo aparece vertical na porção a NE do perfil, marcado por uma elipse verde na Figura 4.3. Este corpo é, de certa forma, correspondente à modelagem gravimétrica, e fica próximo ao contato onde ficam localizadas grande parte das BIFs. Na mesma anomalia há uma variação do corpo magnético, indicado por uma seta. Esta variação ocorre junto com o modelo gravimétrico que na mesma posição apresenta um pequeno alto, da ordem de $1 \mathrm{mGal}$. O corpo magnético, marcado por uma elipse vermelha na figura, está próximo a uma região onde afloram as rochas metassedimentares e há um pequeno baixo, também da ordem de $1 \mathrm{mGal}$, na anomalia Bouguer. Não era esperado um corpo magnético nesta região, porém este pode ser explicado pela presença de formações ferríferas bandadas (BIF) em outras regiões das rochas metassedimentares 1.

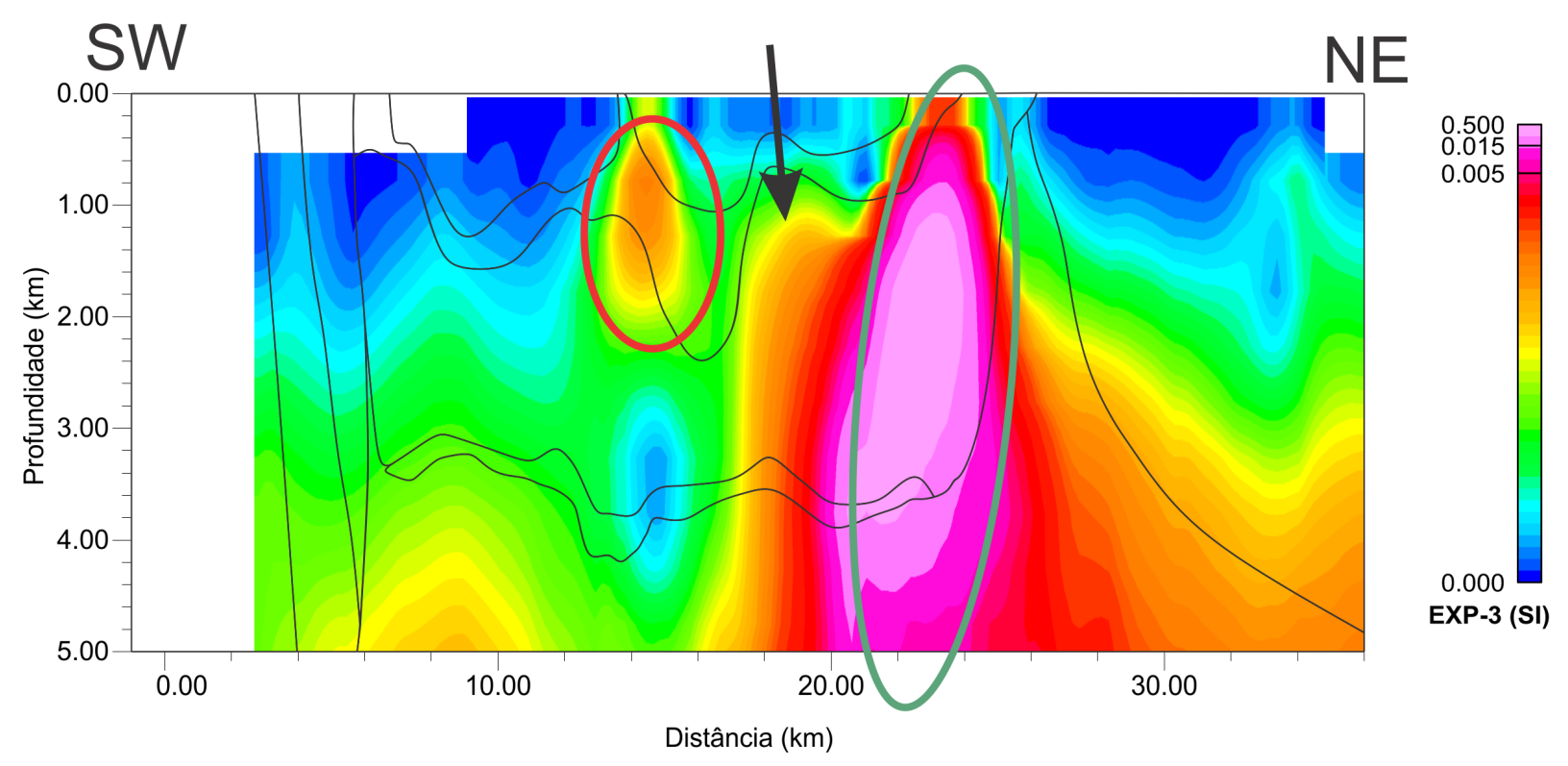

Figura 4.3: Seção MVI do perfil Carioca Serra Grande com a indicação dos principais resultados.

O perfil Granito Jaguara (Figura 3.9) passa sobre uma intrusão granítica (bem caracterizada por um baixo, de cerca de -6 mGal, na anomalia Bouguer) que divide o greenstone belt em dois, um menor a SW com profundidade máxima de, aproximadamente, 1,5 km e outro maior a NE com profundidade máxima de $4 \mathrm{~km}$, um pouco mais raso que nos perfis anteriores. A porção do greenstone belt a SW é a única em que a ultramáfica é aflorante 
e sua modelagem tem grande influência sobre o modelo calculado. A modelagem apresenta grandes variações de topografia dos metassedimentos condizentes com as variações da anomalia Bouguer e a geologia da área. O mesmo granito que apareceu nos modelos Conceição do Pará (em subsuperfície) e Carioca Serra Grande, aparece ao final (NE) desse modelo, porém neste caso ele está em contato com um corpo mais denso (densidade de $2750 \mathrm{~kg} / \mathrm{m}^{3}$ ), que o mapeamento geológico não discrimina. Como o granito está no limite NE do perfil a sua presença é questionável. É indicado uma análise com um perfil mais longo para definir de maneira mais precisa a sua existência, porém como o objetivo do trabalho é a modelagem do GP, este perfil não foi estendido.

A seção de susceptibilidade magnética aparente, resultante da MVI, deste perfil é referente à área Serra Pequi Jaguara e é perpendicular a um grande corpo magnético, assim como o perfil Carioca Serra Grande. Porém, além deste corpo que é caracterizado por uma grande anomalia do campo magnético anômalo, também estão presentes pequenos dipolos (Figura 3.2) que são representados, na seção da MVI, como diversas regiões magnéticas. Essas regiões magnéticas não têm boa compatibilidade com as litologias indicadas pela modelagem gravimétrica, por exemplo, há regiões magnéticas na inversão que estão sobre a intrusão granítica (em laranja) e sobre o gnaisse, rochas que são pouco magnéticas quando comparada com as máficas e metassedimentos com BIFs. Poucos resultados da inversão são coerentes com as variações da fronteira máfica-metassedimento 1. Ao final da seção da MVI, na porção NE, há um grande baixo de susceptibilidade magnética aparente que condiz com o aparecimento dos granitos na modelagem.

O perfil modelado Sul (Figura 3.10) mostra o final do GP. Este perfil apresenta o greenstone belt dividido em dois, uma calha mais extensa a SW e outra mais estreita a NE. Ambas as calhas têm uma profundidade máxima de, aproximadamente, $1 \mathrm{~km}$ indicando um grande afinamento do GP. Ambas as calhas são condizentes com a geologia de superfície. A modelagem gravimétrica separa o greenstone belt pelo Batólito Florestal. O batólito foi modelado com um contraste de densidade inferior aos gnaisses. O mesmo granito presente nos outros modelos (com exceção do modelo Sísmica) está presente no limite NE do modelo. O granito está mapeado pela geologia e novamente a anomalia Bouguer tem uma tendência de baixo sobre ele. A presença do Batólito Florestal e de outros granitos que se interpõem dentro ou muito próximo ao greenstone belt é delimitada nos mapas da primeira derivada vertical e da ASA (Figura 3.3A e B). Na Figura 3.3A e B nota-se de forma expressiva que 
o Batólito Florestal é circundado por material magnético.

A seção MVI não está presente na primeira calha, apenas sobre a calha a NE e termina próxima a sua posição. Pelo mapa da Figura 3.2 se observa que o perfil passa sobre uma porção mais estreita da anomalia magnética, que é coerente com o afinamento da calha apresentado no perfil. A seção da MVI mostra uma região de alta susceptibilidade magnética aflorante, junto à calha modelada, porém a escala dessa seção magnética tem o máximo com magnitude inferior ao restante dos perfis da mesma área invertida (Serra Pequi Jaguara), o que pode indicar uma concentração menor de BIFs. A posição desta região é compatível com a modelagem gravimétrica, ambas apresentam extensões em superfície com valores próximos entre si.

A Figura 4.4 mostra o resultado das modelagens e suas respectivas posições no mapa de anomalia Bouguer. Nesta figura todas as modelagens têm a mesma escala lateral, o que facilita a observação da extensão da calha, que é maior na porção Norte, principalmente na modelagem Conceição do Pará. Na modelagem Carioca Serra Grande a calha já se encontra um pouco mais estreita porém com uma forma parecida com a modelagem Conceição do Pará. Na modelagem Granito Jaguara ela estreita mais e é dividida por um granito. A calha a NE deste modelo apresenta um formato parecido com a modelagem Sísmica que pode indicar um final próximo do greenstone belt na porção Norte que é marcado, como na porção Sul, por um estreitamento e redução da espessura. No perfil Sul ela está dividida, é estreita e rasa. Neste perfil há uma elevação abrupta da base da calha, de $4 \mathrm{~km}$ de profundidade no perfil Jaguara para $1 \mathrm{~km}$ no perfil Sul. Esta característica indica que os contatos do GP com os gnaisses/granitos são verticalizados, apenas a modelagem Sísmica mostra um contato um pouco mais suave nas laterais, porém ainda abrupto. 


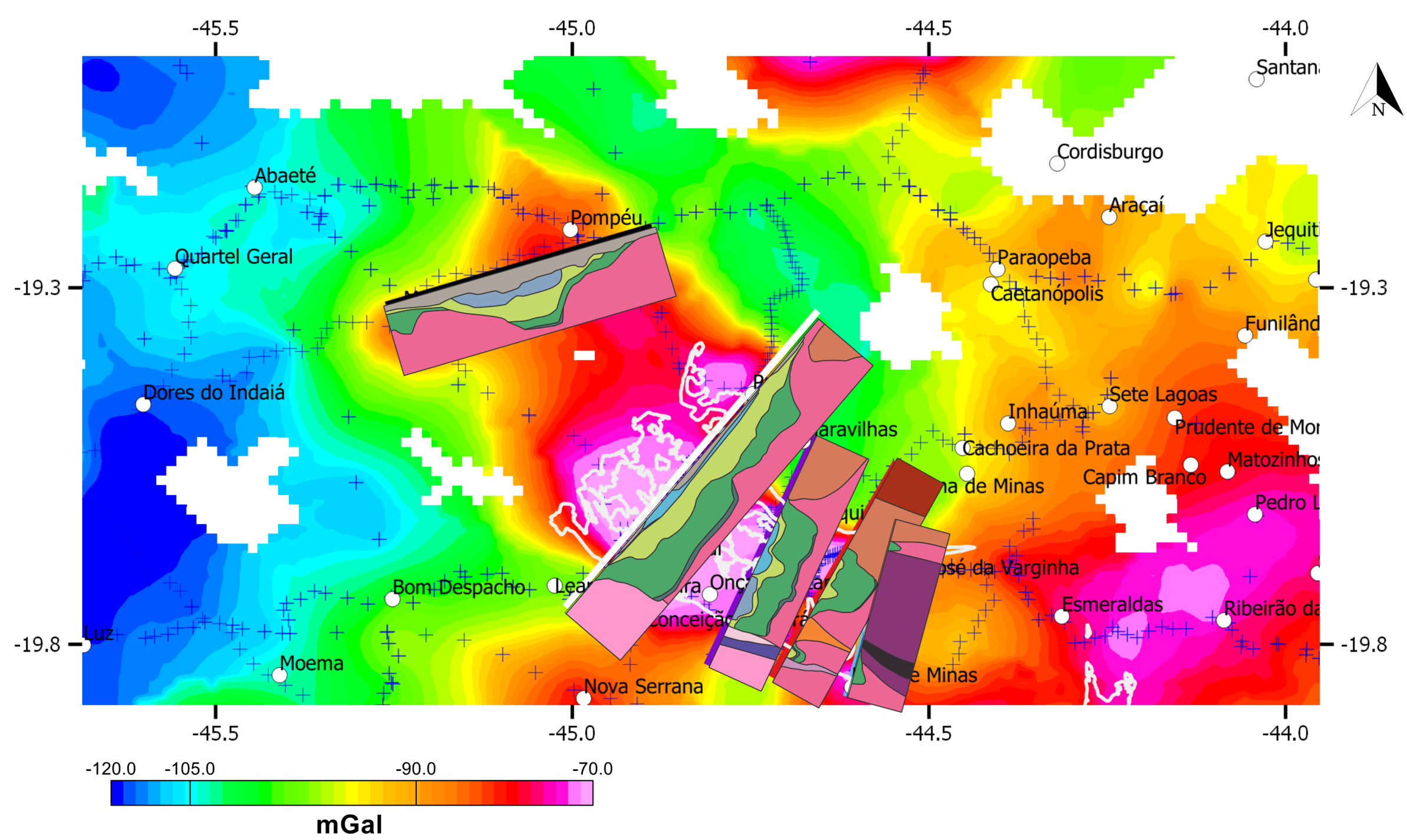

Figura 4.4: Modelagens gravimétricas 2D colocadas sobre o mapa de anomalia Bouguer com a mesma escala lateral. 


\subsection{Limites laterais}

Para estimar os limites laterais do GP foram analisadas as modelagens e em cada limite do GP estabelecido pelos modelos, o valor de anomalia Bouguer correspondente foi anotado. Na Figura 3.10 estão exemplificados estes limites (linhas vermelhas tracejadas na porção superior). Os perfis Granito Jaguara e Sul foram os únicos com quatro limites, dois para cada modelo de greenstone belt. O perfil Sísmica apresentou apenas um limite pois as estações projetadas estão em uma porção mais distante a sul do perfil, onde, aparentemente, o GP continua. Os demais perfis apresentaram apenas dois limites. Os limites estão apresentados na Tabela 3.1

Pela tabela, os limites variam de -100 a -82 mGal, com uma média de -90,2 mGal. O perfil modelado Sísmica (Figura 3.6) e Conceição do Pará (Figura 3.7) apresentam os menores valores, provavelmente em razão de ambos serem cobertos por rochas menos densas e as rochas do greenstone belt estarem mais profundas. Foi escolhido um intervalo de -93 a -87 mGal para desenhar as curvas de isovalor no mapa de anomalia Bouguer com espaçamento de $2 \mathrm{mGal}$ (Figura 3.11). Estas curvas foram desenhadas para mostrar o limite lateral do greenstone belt, uma extensão dos resultados obtidos dos modelos 2D.

Na porção Norte, as curvas de isovalor mais representativas são a -91 mGal e -93 mGal. Estas curvas são as que melhor se adequam aos limites definidos pelas modelagem Sísmica e Conceição do Pará. Devido ao pouco número de estações gravimétricas entre os dois perfis, a precisão do mapa a inferência dos limites laterais do greenstone belt se torna pouco confiável em regiões distantes de estações. Uma feição interessante marcada por estas curvas de isovalor está localizada no extremo noroeste (Figura 4.5). Neste local o greenstone belt parece avançar para oeste causando uma grande assimetria em sua forma como um todo. O mapa de anomalia Bouguer residual, da Figura 3.1B também ressalta essa assimetria.

Abaixo da porção central do greenstone belt, o valor de curva de isovalor que melhor se adequa aos limites estabelecidos pela geologia de superfície e pelos perfis modelados é -87 mGal, apesar que todas as curvas se aproximam nesta porção, não havendo uma diferença grande nos limites definidos por elas. Já mais a Sul, as outras curvas divergem da posição do GP, principalmente na porção SW e no entorno da intrusão granítica, sendo esta curva a mais adequada para definir os limites nesta porção. Uma estimativa da posição lateral 
do GP é apresentada na Figura 4.5, em que a curva de -93 mGal é acompanhada até um pouco a Sul da porção central e então é utilizada a curva de isovalor de -87 mGal.

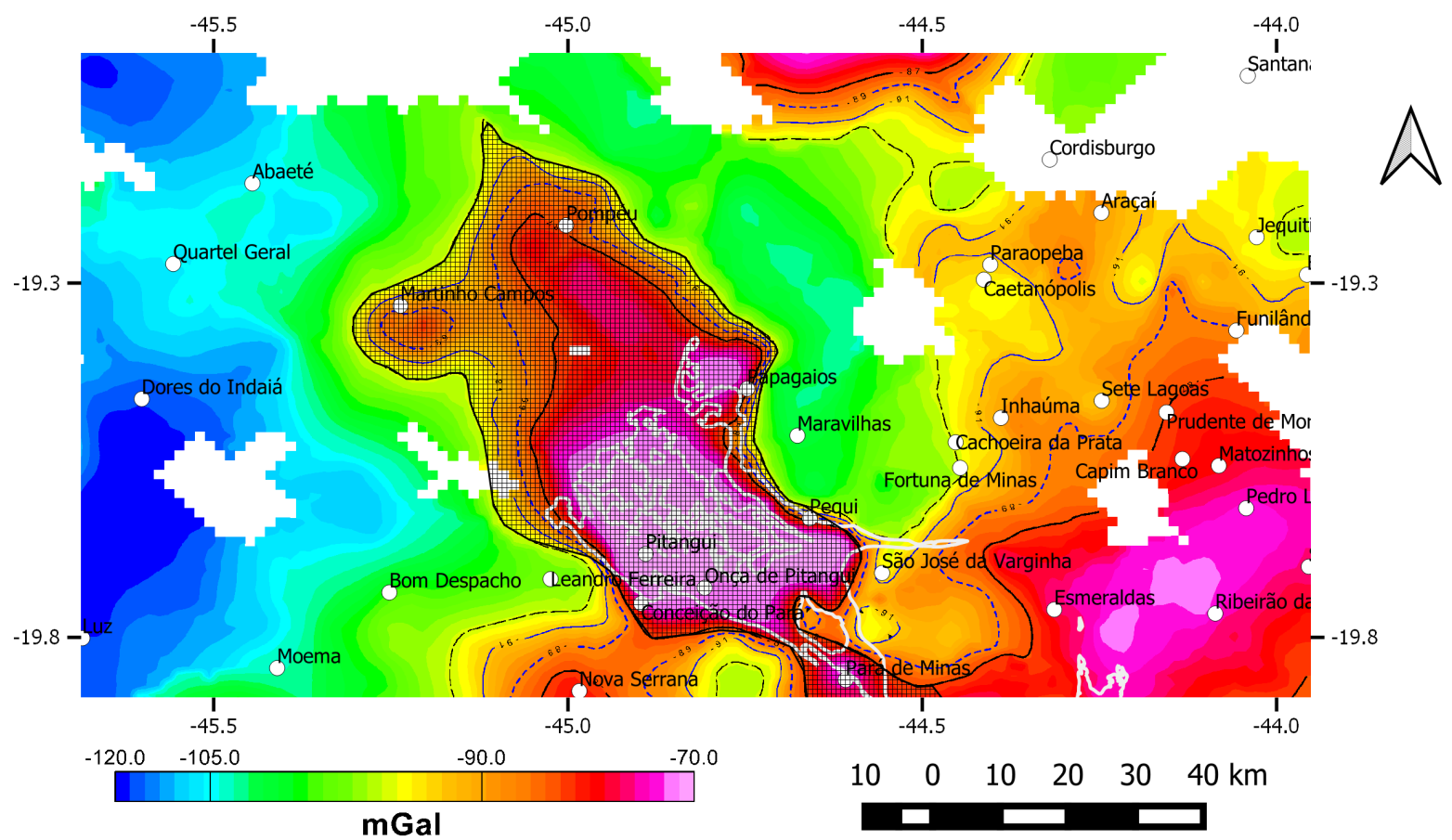

Figura 4.5: Mapa de anomalia Bouguer com as linhas de isovalor. Os valores variam de -93 (linha pontilhada preta), -91 (linha contínua azul), -89 (linha pontilhada azul) e -87 mGal (linha contínua preta). A região hachurada indica a interpretação de onde ficam os limites do GP. 
Capítulo 5

\section{Conclusões}

O presente trabalho trouxe novas informações para uma área com estudos geológicos e geofísicos escassos. A modelagem gravimétrica direta 2D foi bem sucedida principalmente em razão do contraste positivo de densidade das rochas que preenchem o greenstone belt quando comparado aos gnaisses/granitos onde ele está inserido. Apesar do bom resultado das modelagens, a quantidade de estações gravimétricas na região ainda é pouca para uma modelagem mais detalhada e inversão 3D.

A sísmica foi de grande ajuda para a modelagem, mesmo com a impossibilidade de obter os dados brutos para fazer um processamento e obter um modelo de velocidade e posicionamento mais preciso. Apesar disso ela forneceu informações de geometria e profundidade importantes, ajudando a embasar melhor os modelos das outras seções.

A MVI foi, de certa forma, bem sucedida. As anomalias invertidas tinham uma forte remanência e mesmo assim os resultados foram adequados. A inversão foi utilizada, principalmente, para confirmar algumas feições das rochas máficas da modelagem gravimétrica. Em algumas áreas a MVI considerou a presença de dois corpos magnéticos, enquanto a interpretação da gravimetria e a geologia de superfície indicavam apenas um.

A estimativa dos limites laterais do greenstone belt é uma nova informação que pode trazer avanços na geologia, porém, como já mencionado, o número de estações é baixo. É necessário para uma melhor estimativa um maior número de estações gravimétricas de forma a delimitar melhor os limites do GP. 


\section{Referências Bibliográficas}

Alkmim F. F., Martins-Neto M. A., Proterozoic first-order sedimentary sequences of the São Francisco craton, eastern Brazil, Marine and Petroleum Geology, 2012, vol. 33, p. 127

Baltazar O. F., Raposo F. O., Mariana: folha SF. 23-XBI, CPRM, 1993

Blakely R. J., Potential theory in gravity and magnetic applications. Cambridge university press, 1996

Blum M. D. L. B., Pires A. C. B., de Moraes R. A. V., Gravity inversion on granitegreenstone belt areas: Crixás, Guarinos and Pilar de Golás, Brazil, Revista Brasileira de Geociências, 2000, vol. 30, p. 547

Costa M., Romano A., , 1976 Mapa Geológico do Estado de Minas Gerais 1: 1000000: IGA

De Beer J., A geophysical study of the Murchison greenstone belt, South Africa, Revista Brasileira Geosciencias, 1982, vol. 12, p. 105

Ellis R., de Wet B., Macleod I., , 2012 Inversion of magnetic data from remanent and induced sources. ASEG Extended Abstracts 2012: 22nd Geophysical Conference, 1-4

Frizzo C., Takai V., Scarpelli W., Auriferous mineralization at Pitangui, Minas Gerais. In Brazil Gold, vol. 91, 1991, p. 579

Guimarães D., Barbosa O., Mapa Geológico do Estado de Minas Gerais escala 1: 1.000. 000, Serv. Geol. Est. Minas Gerais. Belo Horizonte, MG, 1934, vol. 1 
Gupta V., Thurston P., Dusanowskyj T., Constraints upon models of greenstone belt evolution by gravity modelling, Birch-Uchi greenstone belt, northern Ontario, Precambrian Research, 1982, vol. 16, p. 233

Gwavava O., Ranganai R., The geology and structure of the Masvingo greenstone belt and adjacent granite plutons from geophysical data, Zimbabwe craton, South African Journal of Geology, 2009, vol. 112, p. 277

Le Pape F., Jones A., Jessell M., Perrouty S., Gallardo L., Baratoux L., Hogg C., Siebenaller L., Touré A., Ouiya P., et al., Crustal structure of southern Burkina Faso inferred from magnetotelluric, gravity and magnetic data, Precambrian Research, 2017, vol. 300, p. 261

Marinho M. d. S., Silva M. A. d., Lombello J. C., Di Salvio L. P. P., Silva R. N., Féboli W. L., Brito D. C., Mapa geológico integrado: área de relevante interesse mineral-ARIM. Quadrilátero Ferrífero, subárea faixa Pará de Minas, Pitangui, CPRM, 2018

Marquardt D. W., An algorithm for least-squares estimation of nonlinear parameters, Journal of the society for Industrial and Applied Mathematics, 1963, vol. 11, p. 431

Moritz H., Advanced physical geodesy, Advances in Planetary Geology, 1980

Pinto C., Silva L., Leite C., Mapa Geológico do Estado de Minas Gerais, 1.1. 000.000, Belo Horizonte, CODEMIG-CPRM, 2014

Ramotoroko C. D., Ranganai R. T., Nyabeze P., Extension of the Archaean MadibeKraaipan granite-greenstone terrane in southeast Botswana: Constraints from gravity and magnetic data, Journal of African Earth Sciences, 2016, vol. 123, p. 39

Ranganai R., Structural and subsurface relationships between the Fort Rixon-Shangani greenstone belt and the Nalatale Pluton, Zimbabwe craton, as derived from gravity and aeromagnetic data, South African Journal of Geology, 2013, vol. 116, p. 273

Ranganai R., Whaler K., Ebinger C., Gravity anomaly patterns in the south-central Zimbabwe Archaean craton and their geological interpretation, Journal of African Earth Sciences, 2008, vol. 51, p. 257 
Reis H. L., Suss J. F., Fonseca R. C., Alkmim F. F., Ediacaran forebulge grabens of the southern São Francisco basin, SE Brazil: Craton interior dynamics during West Gondwana assembly, Precambrian Research, 2017, vol. 302, p. 150

Romano A. W., O Supergrupo Rio das Velhas da faixa Mateus Leme-Pitangui-parte meridional do Cráton do São Francisco, MG-e seu sistema de alteração hidrotermal, Revista Geonomos, 1993, vol. 1

Romano A. W., Soares A. C. P., Geologia da folha Pará de Minas SE. 23-ZC-IV, CPRM; UFMG, 2007

Soares M. B., Neto A. V. C., Zeh A., Cabral A. R., Pereira L. F., do Prado M. G. B., de Almeida A. M., Manduca L. G., da Silva P. H. M., de Araújo Mabub R. O., et al., Geology of the Pitangui greenstone belt, Minas Gerais, Brazil: stratigraphy, geochronology and BIF geochemistry, Precambrian Research, 2017, vol. 291, p. 17

Souza Z. S., Luiz J. G., Cruz J. C., Paiva R. N., Geometria de greenstone belts arqueanos da região de Rio Maria (Sudeste do Pará, Brasil), a partir de interpretação gravimétrica, Revista Brasileira de Geociências, 1992, vol. 22, p. 198

Talwani M., Computation of magnetic anomalies caused by two-dimensional bodies of arbitrary shape, Computers in the mineral industries, 1964, vol. 1, p. 464

Talwani M., Worzel J. L., Landisman M., Rapid gravity computations for two-dimensional bodies with application to the Mendocino submarine fracture zone, Journal of geophysical research, 1959, vol. 64, p. 49

Webring M., , 1985 Technical report SAKI; a Fortran program for generalized linear inversion of gravity and magnetic profiles. US Geological Survey,

Yilmaz O., Doherty S., Seismic data processing: Investigations in Geophysics, Society of Exploration Geophysicists, 1987, vol. 2, p. 526 